\title{
Induced Pluripotent Stem Cells: Next Generation Cells for Tissue Regeneration
}

\author{
Ayman Yousif Ibrahim, Mohammad Qasim Mehdi, Abbas Omar Abbas, \\ Abdulrahman Alashkar, Kh. H. Haider* \\ Department of Basic Sciences, SRC, Al-Qassim, KSA \\ Email: "Kh.haider@sr.edu.sa
}

Received 24 January 2016; accepted 27 March 2016; published 30 March 2016

Copyright (C) 2016 by authors and Scientific Research Publishing Inc.

This work is licensed under the Creative Commons Attribution International License (CC BY). http://creativecommons.org/licenses/by/4.0/

c) (i) Open Access

\begin{abstract}
More than two decades of in vitro experimentation supported by the data from experimental animal studies in both small as well as large experimental animal models have culminated into multiple clinical studies worldwide to assess their regenerative potential. Although the data generated from these studies have only met with cautious response from the researchers, efforts are still underway with the hope to refine the different aspects of cell-based therapy approach to develop it into an effective routine therapeutic intervention. Besides others, search for a cell type with optimal characteristics remains an area of intense research. Pluripotent stem cells in general, and induced pluripotent stem cells in particular have gained special attention of researchers due to their ability to adopt a morphofuntionally competent phenotype. They are being considered as surrogate embryonic stem cells albeit without moral and ethical issues of availability and having better immunological acceptability. We provide a head-to-head comparison of ESCs and iPSCs and an overview of stem cell therapy approach converging on the observed advantages of pluripotent stem cells during pre-clinical and clinical studies.
\end{abstract}

\section{Keywords}

ESC, iPSC, Regeneration, Stem Cells, Transplantation

\section{Introduction}

In our pursuit to stay alive and healthy, human beings have been fighting disease since the dawn of time. Our ways have been constantly evolving and so do the options of therapeutic intervention to support the intrinsic repair mechanisms of the biological system during diseased conditions, but the breakthrough we witness today is

\footnotetext{
${ }^{*}$ Corresponding author.
}

How to cite this paper: Ibrahim, A.Y., Mehdi, M.Q., Abbas, A.O., Alashkar, A. and Haider, Kh.H. (2016) Induced Pluripotent Stem Cells: Next Generation Cells for Tissue Regeneration. J. Biomedical Science and Engineering, 9, 226-244. 
unprecedented. Last three decades of medical research have witnessed the emergence of molecular and cellular medicine that has advanced the field from symptomatic intervention to confront the root cause of the disease process at cellular and molecular levels. The newer concept is simple yet technically challenging as it involves "repair, replacement or regeneration of cells, tissues or organs to restore the impaired biological functions" [1].

The regenerative capacity of the tissues and organs varies significantly in different animals. While planarian worms possess the regenerative capacity to compensate for loss of any of their tissues, and even have the competence to produce the entire animal from a single cell [2], homo sapiens are naturally less privileged when it comes to regenerative ability. Hence, in the clinical perspective, researchers have always wondered if we could harness the power of regeneration. Decades of research in characterization of stem cells and exploration of their capacity of multi-lineage differentiation to adopt morphofunctionally competent phenotypes have brought us closer to harnessing their regenerative capability. Our review of literature provides a direct comparison of embryonic stem cells (ESCs) and induced pluripotent stem cells (iPSCs) besides providing a critical appreciation of the progress made thus far in the use of these cells in pre-clinical settings as well as in the clinical perspective for developing pluripotent stem cell-based therapeutic modalities.

Stem cells are discriminated from their somatic cell counterparts on the basis of two important characteristics: their capacity of unlimited undifferentiated self-renewal and the ability to differentiate into various cell lineages in response to appropriate set of cues [3]. In addition to these discerning features, pluripotent stem cells express transcription factors that are characteristic of primitiveness (e.g. Oct3/4, Sox2 and Nanong) [4], and undifferentiated cell markers [5]. Various schemes have been adopted to classify stem cells based on their competence to differentiate into different specialized cell types, tissue source and surface markers [6]. Based on potency features, stem cells can be totipotent, pluripotent, multipotent, or unipotent (Table 1). A totipotent cell can give rise to all embryonic and extraembryonic structures with the zygote being an archetypical example. On the same note, pluripotent stem cells derived from the inner cell mass (ICM) are capable of differentiating into all cell types from the three germ layers ectoderm, mesoderm, and endoderm. Unlike the previously described two cell types, both multipotent and unipotent stem cells exhibit much restricted capacity of differentiation. Adult stem cells found in almost all tissues i.e., skeletal and cardiac muscles, adipose tissue, peripheral blood or bone marrow, belong to the later categories and incidentally are convenient in their acquisition [7].

The pioneering work of Yamanaka et al. has led to the ground breaking discovery that somatic cells can be reprogrammed to pluripotent status [8]. The results of the innovative strategy won the authors laurels of being Nobel laureates besides reinvigorating the interest in the use of pluripotent stem cells. Their decade long search for appropriate combination of transcription factors for reprogramming of somatic cells revealed that forced expression of a quartet of transcription factors including Oct4 (Octamer-4), Sox2 (Sry box containing gene 2), Klf4 (Krupple like factor-4) and c-Myc(c-myelocytomatosis) could successfully transform the mouse skin fibroblasts to pluripotent status (Figure 1). Since the inception of these data, various research groups have attempted to optimize the classical 4-factror protocol to enhance the efficiency of cellular reprogramming of somatic cells besides improving their safety for human application. Noticeable modifications in the classical protocol include attempts to replace and/or reduce the number of transcription factors [9]-[13]. Moreover, there is a shift from usage of integrating viral vector delivery systems to the application of non-integrating viral and virus-free methods to enhance the reprogramming efficiency and safety of iPSCs for human application [14]-[19]. A detailed account of the topic is provided elsewhere in the review.

Table 1. Head-to-head comparison of ASCs, ESCs and iPSCs.

\begin{tabular}{cccc}
\hline Characteristics & ASCs & ESCs & iPSCs \\
\hline Potency & Limited (multipotent or uni-potent) & Pluripotent & Pluripotent \\
Availability & Easy & Difficult & Easy \\
Ethical issues & Less problematic & More problematic & Less problematic \\
Immunogenicity & Less problematic & More problematic & Less problematic \\
Self-renewing period & Shorter & Longer & Longer \\
Teratogenicity & Less tumorigenic & Yes & Yes \\
\hline
\end{tabular}

ASCs: Adult stem cells; ESCs: embryonic stem cells; iPSCs: Induced pluripotent stem cells. 


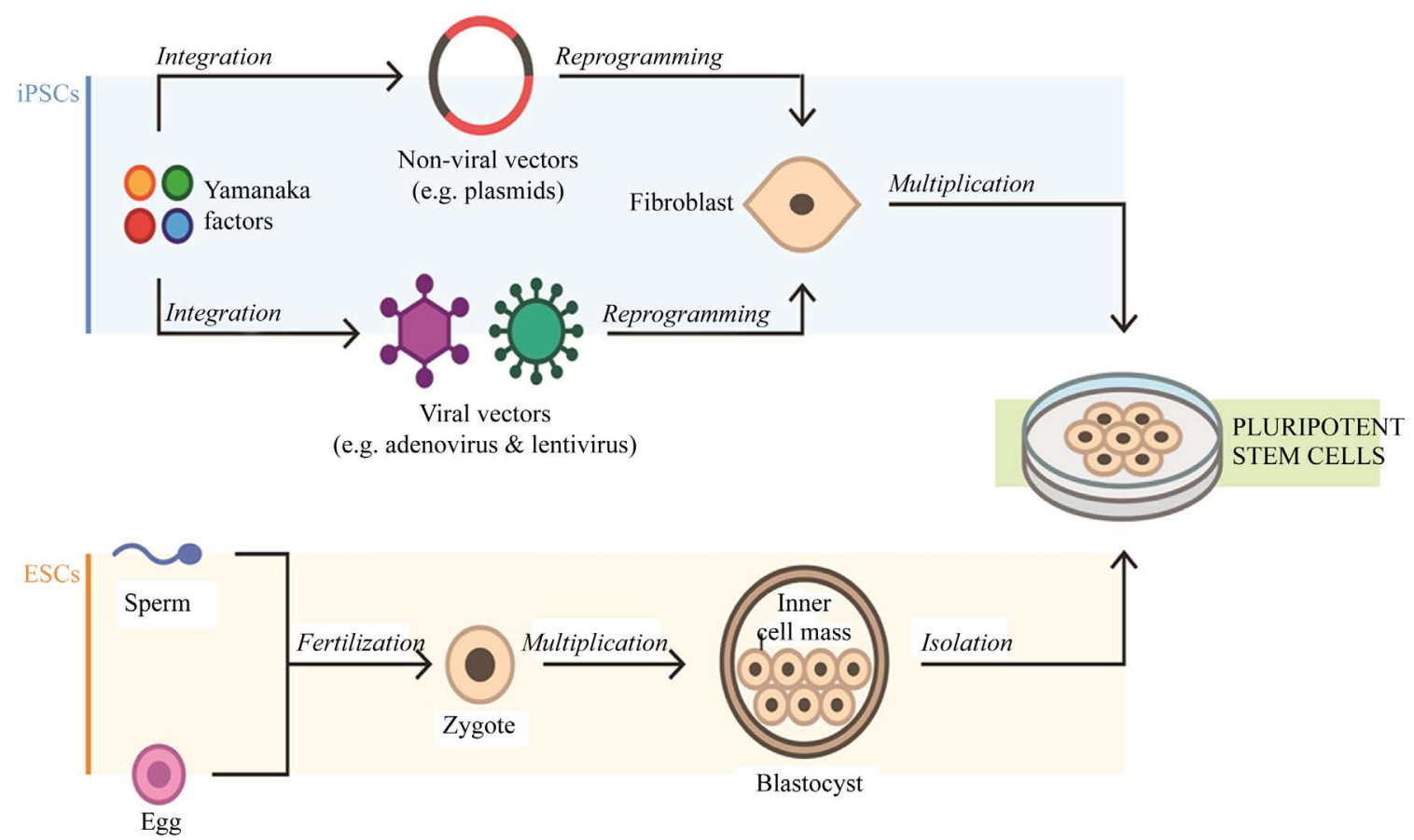

Figure 1. Isolation and production of ESCs and iPSCs.

\section{Embryonic Stem Cells}

Murine ESCs (mESCs) were first reported in 1981 in two back to back publications when the cells were identified as pluripotent with the capacity to form a chimeric animal as well as teratocarcinoma in an experimental immunodeficient mouse model [20] [21]. The cells were isolated from the in vitro cultures of the mouse blastocysts and showed conclusive evidence of multi-lineage differentiation. These data showed the feasibility of isolation of pluripotent cells from non-inbred embryos. Since these pioneering studies, multiple mESC lines from different research groups have been established and made available for further investigations (Table 2).

One and a half decades later, marking the advent of a new era in the field of medicine, Thompson et al. reported the first human ESC line using fresh or frozen cleavage stage embryos produced by in vitro fertilization for clinical use [22]. The authors reported 5 cell lines derived from 5 different embryos with all of the derivative cell lines showing normal karyotype. Typically, the cells exhibited distinctive features of an ESC including larger nucleus to cytoplasm ratio, high telomerase activity and continuous undifferentiated propagation in vitro culture for 5 - 6 months before cryopreservation. Moreover, the cell lines differentiated into cell types from all the three germ layers and formed teratomas when injected into immunodeficient mice. Until the writing of the manuscript, NIH website (http://grants.nih.gov/stem_cells/registry/current.htm) recorded 351 human ESC lines eligible for research use in the NIH funded projects and 34 ESC lines are under review and pending approval (http://grants.nih.gov/stem_cells /registry/pending.htm). Since the publication of the first report, hESC isolation and procurement protocols have been advanced to obtain clinical grade hESCs. Immunosurgery to isolate ICM from the blastocysts remains the most commonly employed method, however, the use of xeno-products during subsequent manipulations restricts the clinical application of the derivative cell lines [23]. Protocols based on mechanical manipulation and enzymatic digestion using combination of collagenase IV, dispase, and trypsin have also been reported [20] [24]. Although the use of enzymatic digestion requires less manipulation and can be efficiently applied on a large scale as compared to mechanical methods of isolation of hESC, use of enzymes causes genetic abnormalities in the developed cell lines [25]-[27]. In order to circumvent these methodological caveats, a laser beam-based system was reported to isolate ICM from trophoectoderm [28]. The technique was based on laser-assisted drilling of a hole in the zona pellucida and the isolated cells were plated in xeno-free culture conditions supported by the feeder cells. Despite these advancements, none of the studies published thus far has attempted to compare these protocols in terms of efficiency as well as the characteristic advantages of their respective derivative cell lines. 
Table 2. ATCC Mouse (Mus musculus) ESC lines for research.

\begin{tabular}{|c|c|c|}
\hline o & G-Olig2 & \#SCRC-1037 ${ }^{\mathrm{TM}}$ \\
\hline 0 & AB2.2 & \#SCRC-1023 ${ }^{\mathrm{TM}}$ \\
\hline 0 & EDJ\#22 & \#SCRC-1021 ${ }^{\mathrm{TM}}$ \\
\hline o & ESF 158 & \#SCRC-1016 \\
\hline$\circ$ & B6/BLU & \#SCRC-1019 \\
\hline o & SCC\#10 & \#SCRC-1020 \\
\hline o & CE-1 & \#SCRC-1038 ${ }^{\mathrm{TM}}$ \\
\hline o & RW.4 & \#SCRC-1018 \\
\hline ० & R1 & \#SCRC-1011 ${ }^{\mathrm{TM}}$ \\
\hline o & R1/E & \#SCRC-1036 ${ }^{\mathrm{TM}}$ \\
\hline 0 & 7AC5/EYFP & \#SCRC-1033 $^{\mathrm{TM}}$ \\
\hline 0 & CE3 & \#SCRC-1039 \\
\hline 0 & J1 & \#SCRC- $1010^{\mathrm{TM}}$ \\
\hline
\end{tabular}

A direct comparison of mESCs and hESCs centred on the analysis of more than 400 genes has been reported [29]. Both cell types were cultured under standard set of conditions to support their undifferentiated status. The results revealed similarities in pluripotency determinant gene profile but showed absence of differentiation specific markers. Together, these data constituted a signature profile of a typically undifferentiated ESC. Despite having commonality in characteristics, both the cell types differed in their morphology, expression of markers such as stage specific embryonic antigen (SSEA)-1, SSEA4, vimentin, fibroblast growth factor-4 (FGF4) and trophoectoderm markers [29]. Moreover, the two cell types differed in their requirement of leukaemia inhibitory factor (LIF) for sustenance of self-renewal through high rate of cell proliferation and concomitant maintenance of undifferentiated pluripotency. Molecular mechanistic studies revealed that downstream of LIF receptor (LIF-R) and gp130 complex (both of which are hallmarks of mESCs), the activation of STAT3 significantly contributed in the undifferentiated self-renewal [30]. Although LIF independent self-renewal of hESCs remains their hallmark, there are reports that some mESCs may follow LIF independent pathway for their self-renewal without undergoing differentiation [31]. Experiments with both mESCs and hESCs have shown that transcription factor Nanog was expressed in ESCs as long the cells maintained their pluripotency irrespective of the cell type [32]. It is generally considered that endogenous Nanog has integral role in ESCs self-renewal in addition to the growth factor mediated stimulation of STAT3. A direct comparison of mESCs and hESCs is given in Table 3.

\section{Culture and Differentiation Characteristics of ESCs}

The most logical culture conditions for hESCs should mimic their natural habitat and microenvironment in the blastocyst to ensure their undifferentiated culture and propagation in vitro. The earlier studies frequently used mouse embryonic fibroblast (MEF) feeder layer as an essential component for in vitro cultures of ESC. The rationale behind the use of MEF as substrate was to enhance adhesion in the ESC and support their tightly packed 3-D growth similar to the embryo and to aid in nutrient provision [33]. Nevertheless, many applications of ESCs, especially their clinical compliance, necessitate optimized protocols to ensure culture conditions which are adherent to the ethical standards and in line with good manufacturing practices (GMP). Consistent with these prerequisites, feeder cells of human-origin including fibroblast feeder cells derived from fallopian tube epithelium, fetal foreskin, muscle, bone marrow, or amniotic epithelium have been successfully used as replacement of MEF [34]-[38]. Additionally, protocols for culturing hESCs have been developed in feeder-free conditions using matrigel and fibronectin. The hyaluronic acid (HA) hydrogel is so far the most superior matrix for maintaining undifferentiated hESCs, as it mimics the essential components of the ECM in the embryos such as bFGF, insulin, ascorbic acid, laminin, and activin-A, and also grants hESCs to retain their maximal differentiation capacity [39]. 
Table 3. Mouse ESC vs human ESCs.

\begin{tabular}{|c|c|c|}
\hline & mESCs & hESCs \\
\hline Morphology & Diverse & Rounded with sharp boundaries \\
\hline In vitro culture requirements & LIF inhibits differentiation & $\begin{array}{l}\text { MEF or Human Feeder Cell Layer } \\
\text { (recently, feeder-free culture is possible) }\end{array}$ \\
\hline Replication time & $\sim 12$ hours & $\sim 36$ hours $^{4}$ \\
\hline Antigenic phenotype & SSEA-1 & SSEA-3, SSEA-4 $4^{4}$ \\
\hline Vimentin & Absent & Present \\
\hline Trophoectoderm markers & Absent & Present \\
\hline$\beta$-III tubulin & Present & $\beta-5$ tubulin present \\
\hline LIFR & High & Low/variable \\
\hline Gp-130 & High & Low/variable \\
\hline FGF4 & High & Absent \\
\hline HRASP & Required & Pseudogene \\
\hline E-hox & Required & No orthologue present \\
\hline Fox-D3 & Present/required & Low/absent \\
\hline Lineage induction by Oct4 & Mesoderm and Endoderm & Endoderm $^{2}$ \\
\hline Lineage induction by SOX2 & Ectoderm and Mesoderm & $\begin{array}{l}\text { Not well-established }{ }^{2} \text { (it's importance for hESC is } \\
\text { yet to be established as it is missing in some lines) }\end{array}$ \\
\hline $\begin{array}{l}\text { NANOG's role in maintaining } \\
\text { stem-cell-features }\end{array}$ & Pluripotency only & Pluripotency and self-renewal ${ }^{2}$ \\
\hline
\end{tabular}

${ }^{1}$ Ginis I, Luo Y, Miura T, et al. Differences between human and mouse embryonic stem cells. Developmental Biology. 2004; 269(2):360-380. ${ }^{2}$ Schnerch A, Cerdan C, Bhatia M. Distinguishing between mouse and human pluripotent stem cell regulation: The best laid plans of mice and men. Stem Cells. 2010; 28(3):419-430. ${ }^{3}$ Bhattacharya B, Miura T, Brandenberger R, et al. Gene expression in human embryonic stem cell lines: unique molecular signature. Blood. 2004; 103(8):2956-296. ${ }^{4}$ Gepstein L. Derivation and potential applications of human embryonic stem cells. Circ Res. 2002; 91(10):866-876.

Besides feeder layer, LIF remains an indispensable component of culture medium for undifferentiated maintenance of mESCs in vitro culture conditions [40]. However, significance of the presence of LIF for undifferentiated propagation of hESCs remains contentious. Molecular studies have shown that human LIF can induce activation of JAK-STAT3 signalling in hESCs however, these molecular events do not help hESCs in undifferentiated propagation [41]. When grown in non-adherent suspension culture conditions, ESCs spontaneously transform into globular embryoid bodies (EBs) containing ESCs differentiating to form cells from all the three germ layers. EBs can be induced to differentiate into various lineages, i.e., neurons, cardiomyocytes, pancreatic $\beta$-cells, haematopoietic progenitors, muscle cells, endothelial progenitors, etc. by the addition of specific growth factors and ECM proteins (Table 4). For example, treatment with retinoic acid induces neuroectodermal differentiation of ESCs by initiating a cascade of intermediate unstable differentiation states via induction of the neuronal specific transcription factor Nurr-1 [42]. Similarly, treatment with nicotinamide increases the earliest cardiac-specific transcription factor Csx/Nkx2 that eventually forms the cardiomesoderm [43] [44]. ESCs can be used to study normal human embryonic development and pathological processes that allows researchers to extensively examine the normal/disease processes in vitro. These in vitro data can be extrapolated to treat incurable diseases such as Alzheimers, Parkinson’s disease, diabetes, heart disease/failure, spinal cord injuries and 
Table 4. In vitro differentiation of ESCs and iPSCs in to different cell lineages.

\begin{tabular}{|c|c|c|c|c|}
\hline \# & Experimental conditions & Cell type used & Tissue derived & Reference \\
\hline 1 & All-trans retinoic acid & hESCs & Smooth muscle cells & Huang et al., 2006 \\
\hline 2 & Co-culture with fetal liver stromal cells & hESCs & Functional erythrocytes & Ma et al., 2008 \\
\hline 3 & Transient reactivation of c-Myc after reprogramming & $\begin{array}{l}\text { Human dermal fibroblast } \\
\text { derived hiPSCs }\end{array}$ & $\begin{array}{l}\text { Megakaryocytes and } \\
\text { Platelets }\end{array}$ & $\begin{array}{l}\text { Takayama et al., } \\
\quad 2010\end{array}$ \\
\hline 4 & $\begin{array}{l}\text { Sequential treatment with activin A + BMP4 + FGF2 + } \\
\text { HGF }\end{array}$ & Fibroblast derived hiPSC & Hepatocyte-like cells & $\begin{array}{l}\text { Si-Tayeb K et al, } \\
2010\end{array}$ \\
\hline 5 & $\begin{array}{l}\text { Mouse ESCs treatment with various concentrations of } \\
\text { Simvastatin }\end{array}$ & Osteogenic Progenitors & $\begin{array}{l}\text { Successful osteogenic } \\
\text { differentiation }\end{array}$ & $\begin{array}{l}\text { Pagkalos et al., } \\
2010\end{array}$ \\
\hline 6 & Pro-intestinal culture + activin + Wnt3A+ FGF4 & hiPSCs and hESCs & Intestinal tissue & Spence et al., 2011 \\
\hline 7 & $\begin{array}{l}\text { Feeder free + FGF inhibitor: SU5402, MEK inhibitor: } \\
\text { PD184352, and GSK3 inhibitor: CHIR99021) }\end{array}$ & Rat ESCs & Cardiomyocytes & Cao et al., 2011 \\
\hline 8 & $\begin{array}{c}\text { Matrix sandwich + sequential treatment with Activin A, } \\
\text { BMP4, \& bFGF }\end{array}$ & $\begin{array}{l}\text { Foreskin fibroblast derived } \\
\text { hiPSCs }\end{array}$ & Cardiomyocytes & $\begin{array}{l}\text { Zhang J et al., } \\
\quad 2012\end{array}$ \\
\hline 9 & $\begin{array}{c}\text { Activin + (SB431542+ Noggin })+(\text { EGF + FGF10 + } \\
\text { KGF + Wnt3a) }\end{array}$ & Fibroblast derived hiPSC & Alveolar type I and II cells & $\begin{array}{l}\text { Shaedi } M \text { et al., } \\
2013\end{array}$ \\
\hline 10 & $\begin{array}{c}\text { Wnt pathway activator, CHIR99021, and either AM580 } \\
\text { or TTNPB }\end{array}$ & hiPSCs/hESCs & Kidney lineage cells & Araoka et al., 2014 \\
\hline 11 & $\begin{array}{l}\text { Retinoic acid and BMP4 treatment and culture on } \\
\text { Collagen-I \& IV dishes }\end{array}$ & hiPSC & keratinocytes & Kogut et al., 2014 \\
\hline 12 & High (60\%) Oxygen culture conditions & Mouse ESCs and hiPSCs & $\begin{array}{l}\text { Endocrine progenitors } \\
\text { (Insulin producing) }\end{array}$ & Hakim et al., 2014 \\
\hline
\end{tabular}

BMP4: Bone morphogenetic factor-4; FGF2: Fibroblast growth factor-2; GSK: Glycogen synthase kinase; HGF: hepatocyte growth factor; hiPSCs: human induced pluripotent stem cells; hESCs: human embryonic stem cells; WNT3a: Wingless-Type MMTV Integration Site Family, Member 3A. 1. Huang H, Zhao X, Chen L, Xu C, Yao X, Lu Y, Dai L, Zhang M. Differentiation of human embryonic stem cells into smooth muscle cells in adherent monolayer culture. BiochemBiophys Res Commun. 2006; 351:321-327. 2. Ma F, Ebihara Y, Umeda K, Sakai H, Hanada S, Zhang H, Zaike Y, Tsuchida E, Nakahata T, Nakauchi H, Tsuji K. Generation of functional erythrocytes from human embryonic stem cell-derived definitive hematopoiesis. PNAS, 2008; 105(35): 13087-13092. 3. Takayama N, Nishimura S, Nakamura S, Shimizu T, Ohnishi R, Endo H, Yamaguchi T, Otsu M, Nishimura K, Nakanishi M, Sawaguchi A, Nagai R, Takahashi K, Yamanaka S, Nakauchi H, Eto K. Transient activation of $c-$ MYC expression is critical for efficient platelet generation from human induced pluripotent stem cells. J. Exp. Med. 2010; 207(13): 2817-2830. 4. Si-Tayeb K, Noto FK, Nagaoka M, Li J, Battle MA, Duris C, North PE, Dalton S, Duncan SA. Highly efficient generation of human hepatocyte-like cells from induced pluripotent stem cells.Hepatol. 2010; 51(1):297-305. 5. Pagkalos J, Cha JM, Kang Y, Heliotis M, Tsiridis E, Mantalaris A. simvastatin induces osteogenic differentiation of murine embryonic stem cells. J Bone and Mineral Res., 2010; 25(11): 2470-2478. 6. Spence JR, Mayhew CN, Rankin SA, Kuhar MF, Vallance JE, Tolle K, Hoskins EE, VV, SI, AM NF, Wells JM. Directed differentiation of human iPSCs into intestinal tissue in vitro. Nature. 2011; 470:105-109. 7. Cao N, Liao J, Liu Z, Zhu W, Wang J, Liu L, Yu L, Xu P, Cui C, Xiao L, Yang H-T. In vitro differentiation of rat ESCs into functional cardiomyocytes. Cell Res. 2011,21:1316-13. 8. Zhang J, Klos M, Wilson GF, Herman AM, Lian X, Raval KK, Barron MR, Hou L, Soerens AG, Yu J, Palecek SP, Lyons GE, Thomson JA, Herron TJ, Jalife J, Kamp TJ. ECM promotes highly efficient cardiac differentiation of human pluripotent stem cells: the matrix sandwich method.Circ Res. 2012; 111(9): 1125-36. 9. GhaediM, Calle $E A$, Mendez $J J$, Gard $A L$, Balestrini $J$, Booth $A$, Bove $P F$, Gui $L$, White ES, Niklason $L E$. Human iPS cell-derived alveolar epithelium repopulates lung extracellular matrix. $J$ Clin Invest. 2013;123(11): 4950-4962. 10. Araoka T, Mae S-i, Kurose Y, Uesugi M, Ohta A, Yamanaka S., Osafune K. Efficient and rapid induction of human ipscs/escs into nephrogenic intermediate mesoderm using small molecule-based differentiation methods. PLoS ONE, 2014, 9(1). 11. Kogut I, Roop DR, Bilousova G. Differentiation of human induced pluripotent stem cells into a keratinocyte lineage. Methods Mol Biol. 2014; 1195: 1-12. 12. Hakim F, Kaitsuka T, Raeed JM, Wei FY, Shiraki N, Akagi T, Yokota T, Kume S, Tomizawa K. High oxygen condition facilitates the differentiation of mouse and human pluripotent stem cells into pancreatic progenitors and insulin-producing cells. J Biol Chem. 2014; 289(14):9623-38.

stroke which contribute enormous burden to the health system. There is a general perception that hESCs hold the solution for various reproductive health problems not involving gametes such as endometrial damage, erectile dysfunction and vaginal atrophy. However, no conclusive results have been obtained which back these claims [45].

\section{Impediments in ESCs Use in Clinical Settings}

Procurement of human embryos exclusively for the purpose ESC isolation has always remained morally and ethically contentious. There has been a long-standing heated argument amongst the researchers as well as the general public on the religious, moral and cultural aspects of the issue [46]. Adding more to the controversy to this debate is the issue of abortion/disposal of human embryos subsequent to their use in the IVF clinics. Furthermore, extended storage of hESCs may cause chromosomal abnormalities such as trisomy 12 and 17 and ge- 
netic amplification at 20q11.21 which is associated with oncogenic transformations [25] [27] [47]. These abnormalities are generally associated with the genes determinant of pluripotency, cell proliferation, and antiapoptosis, which is remarkably similar to the genetic changes observed in many human tumors [47]. Besides ethical and moral issues, the "non-self" nature of ESCs appends to the poor immunological acceptance of their derivative tissue by the recipient despite enjoying immunopriviledged status in their undifferentiated state. Hence, an adjunct immunosuppression therapy is essential to augment their post engraftment acceptance. The immunopriviledged status of undifferentiated hESCs has been attributed to low level expression of MHC-I and absence of MHC-II and co-stimulatory molecules CD80 and CD89. Upon differentiation, the derivative tissue expresses MHC-I thus rendering the derivative tissue immunogenic [48] [49]. There are reports however, that the cells derived from ESCs have low immunogenicity and even possess anti-inflammatory and immunosuppressive properties [50] [51].

Another concern that has seriously hampered the progress of hESCs to routine clinical application is their robust teratogenic potential [52]. Despite ample evidence from published data, the underlying reason and mechanism of hESC's teratogenic potential is largely undetermined. Given that hESCs share many similarities with the embryonic carcinoma cells (ECCs), hence tumorgenicity is one of the shared characteristic of hESCs with ECCs [53]. Moreover, teratogenicity being inherent characteristic of pluripotent stem cells; it is also associated with adaptation of the cells to the environment thus activating the oncogenic networks in the cells at molecular levels [53]. Attempts are underway to discriminate between partially transformed ESCs and normal ESCs as a strategy to curtail their tumorgenicity.

\section{ESCs and the NIH Policies}

Unlike the concerns pertaining to immunological acceptance and tumorigenic potential of ESC that warrant pure scientific effort for resolution, divide in the scientific and social circles regarding ethical/moral issues seem deeper. Whereas the Bush administration's policy about hESCs to ban federal funding for newly created hESCs lines dampened the hope in the scientific community involved in stem cell research, the Executive Order 13505 issued by President Obama in 2009 has been quite encouraging [54]. According to the new guidelines, embryos could only be obtained after proper informed consent from the donor without payments, cash or rewards. Moreover, the new NIH guidelines allow the use of embryos created using IVF for clinical use but are no longer needed for that purpose, provided that the donor has agreed to do so [55]. The Guidelines also apply some restrictions on the donors. Firstly, the donor is not allowed to choose the recipient of their cellular transplants including themselves. Secondly, the donor receives information that the research is not intended to provide direct medical benefit to the donor. Thirdly, in case that the results of research using the derived hESCs end up with commercial potential, the donor will not receive financial or any other benefits from any such commercial development. It is significant to note that the guidelines do not disqualify a donor from benefitting from the medical outcomes of stem cell research and treatments that may be developed in the future.

\section{Induced Pluripotent Stem Cells}

iPSCs are surrogate ESCs as they share common characteristics such as the expression of pluripotency markers, self-renewal, differentiation capacity to form cells from all the three germ layers, unlimited proliferative potential and teratogenicity post engraftment [56]. The acceptance of iPSCs as an alternative to ESCs has grown over the years as it surmounts the obstacles posed by the use of ESCs. Firstly, iPSCs generation does not involve technically more tedious methodologies such as procurement of oocytes and somatic nuclear transfer [57]. Secondly, unlike ESCs, there are no bioethical issues surrounding the iPSCs as a continuous source of autologous and disease specific pluripotent stem cells. Despite close similarities, iPSCs have distinct features in comparison with their ESC counterparts including maintenance of epigenetic memory of the mother cells from which they have been derived [58] [59]. Similarly, in contradiction to the general perception that iPSCs derived from autologous source would be immunologically more acceptable, recent studies have probed the immunological acceptability of iPSCs derived from autologous donor cells and warrant caution before use in the clinical settings [60]. During the course of a study to ascertain the process of pluripotency induction, a set of more than 24 candidate transcription factors relevant to pluripotency in ESCs was tested to determine the necessary factors for the development of iPSCs. Many members of the set of the tested genes showed oncogenic potential when used on animal samples. Subsequent to a series of experiments, the authors were able to shortlist the quartet of essen- 
tial transcriptional factors i.e., Oct3/4, c-Myc, Sox2 and Klf4, to successfully develop iPSCs [61]. Bisulfite genomic sequencing revealed that the promoters of both Fbx15 and Nanog were demethylated while the promoter of Oct3/4 remained methylated in the transformed cells. Although the efficiency of transformation was very low, the results were significant in terms of transformation of the field of stem cell therapy from being stagnant to vibrant. It wasn't until 2007 that human iPSCs were reported in one study each published by Thomson et al. at University of Wisconsin-Madison and Yamanaka et al. at Kyoto University [9] [61]. Whereas the latter study generated human iPSCs from adult dermal fibroblasts with the classical quartet of transcription factors Oct4, Sox2, Klf4 and c-Myc, the former used a combination of Oct4, Sox2, Nanog and Lin28 for successful induction of pluripotency. The iPSCs thus generated in both the studies were similar to ESCs in pluripotency and differentiation characteristics.

\section{Advances in Reprogramming Strategies to Generate iPSCs}

Due to incomplete understanding of the underlying molecular mechanisms that lead to cellular transformation from terminally differentiated status to pluripotency, the protocols of reprogramming are less than optimal in efficiency. Three years after successful reprogramming of mouse fibroblasts using classical quartet of transcription factors, two different models, elite model and stochastic model, were put forth to explain the reprogramming process [62]. According to the elite model, not all somatic cells were reprogrammable whereas the stochastic model predicted that all somatic cell types might be reprogrammed with the involvement of epigenetic alterations enroute to pluripotency [63]. The stochastic model was supported by many independent studies showing successful reprogramming of different cell types including skin fibroblast [61], dental pulp [64], peripheral blood cells [65], T-cells [66], bone marrow cells [67], skeletal myblasts [68] and many others. On the contrary, the elite model relies on a recently published study that the presence of multilineage-differentiating stress enduring (Muse) cells is predominantly responsible for iPSC generation from human fibroblast [69]. An interesting feature of Muse cells is that these cells, either derived from bone marrow mesenchymal stem cells or human fibroblasts, express CD40, CD90 and CD105 markers of mesenchymal lineage besides concomitant expression of pluripotency marker SSEA3 (stage specific embryonic antigen 3). Although much controversy shrouds the exactness of a model explaining the mechanism of somatic cell reprogramming, it is generally accepted that reversal of differentiated somatic cells to pluripotency is a step-wise transition rather than spontaneous/abrupt change of status [70]. The earlier deterministic phase involves mesenchymal to endothelial transition (MET) followed by stochastic phase with random probability of distribution. The stochastic phase is typified by specific microRNA expression profile, histone modifications and changes in DNA methylation status [70]. Nevertheless, the stochastic model does not fully appreciate the role of microRNA (miRNA) in MET. The maturation phase transits into stabilization of stem cell circuity activation once the cascade of these specific changes has occurred. An interesting study involving single cell reprogramming was carried out to study the molecular events that precede the transformation of a somatic cell to pluripotency [71]. Recent data vividly support a substantial role of epigenetic modifications during the cascade of reprogramming events in many types of somatic cells. A detailed description of the role of epigenetics has been discussed under "Epigenetics of iPSCs".

The protocols for direct reprogramming of somatic cells to pluripotency by ectopic expression of exogenous transcription factors have evolved significantly over the years. The modified protocols range from replacement of some members of the classical quartet to reduce the number of transcription factors and the delivery strategy from viral to non-viral vectors and even DNA-free methods based on small molecule treatment and protein transduction methods using cell penetrating peptide moieties. Protocols have also been developed by combinatorial approach based on mix of different strategies. The main motive behind refining the reprogramming protocol is three-fold: to enhance the reprogramming efficiency, eliminate the use of oncogenic factors from the classical quartet, and to make the derivative cells safer for clinical applications.

The earlier studies for refining the protocol were envisioned to understand the role of each one of the four transcription factors of reprograming. It was considered that the presence of cMyc contributed towards immortality and active status of chromatin, Oct $3 / 4$ changed the fate of the cell from tumour cells to ESC-like cells, Klf4 suppressed senescence while Sox2 was responsible for pluripotency of the derivative iPSCs [72]. The collective effect of ectopic expression of transcription factors altered the DNA methylation status, gene expression profile and chromatin status in the newly transformed cells similar to the ESCs [73]. Following the success of reprogramming protocols with 4 factors, plethora of publications ascertained the feasibility of replacingor re- 
ducing the number of transcription factors required for successful reprogramming of somatic cells [10] [66] [74] [75]. Ectopic expression of as little as single factor i.e., Oct4, either alone or in combination with small molecules has been attempted for successful reprogramming of somatic cells [76]-[79]. These studies also highlight the paramount significance of Oct4 and its indispensable part for success of any reprogramming protocol. The usage of small molecules to enhance the reprogramming efficiency is increasingly becoming popular due to their well-defined chemical nature, permeability to cross the cell membrane, impacting the chromatin status and various signalling pathways and allowance to adjust the concentration required to achieve the desired consequence [80]. Additionally, versatility of reprogramming strategy of somatic cells has been tested in cells from different species including mouse [8] [14], rat [81] [82], monkey [83], porcine [84] [85], and humans [8] [9]. As a part of the strategy to enhance the efficiency of reprogramming, cells from different tissue sources have been successfully employed [67] [68] [86]-[89]. This was based on the understanding that the inherent expression of one or more pluripotency factors may reduce their dependency on exogenous factors thus making these cells labile to undergo transformation to pluripotent status. For example, neuronal progenitor cells which endogenously express higher level of Sox2 were successfully reprogrammed to pluripotency by transduction of a combination of exogenous Oct3/4, Klf4 and cMyc [90].

One of the important aspects of reprogramming strategy under intense scrutiny has been the vectors for genetic manipulation of cells with pluripotency transcription factor genes. Given their marked ability and efficiency of transduction in a variety of cells with ease, the use of viral-vectors is fairly popular strategy [91]. Specifically, different viral vectors, i.e., retrovirus [61], and lentivirus [9] have been successfully used for manipulation of the donor cells. The downside of viral vectors is their tendency to randomly integrate the transgenes into the host genome besides being difficult to dislodge once reprogramming has been accomplished [92]. Two nonintegrating viruses, adenovirus and Sendai virus have gained popularity in the field of iPSCs reprogramming. Nevertheless, the increased rate of tetraploid cells presence after the use of adenovirus remains a big disadvantage [62]. On the other hand, Sendai virus provides a superior option because of its largely non-integrating potential, safety and overall comparatively less disadvantages [93]. Again, it remains a formidable challenge to remove the replicating virus from the reprogrammed cells with the use of Sendai virus. In order to replace viral vectors, a variety of non-viral methods have been designed and applied successfully [16]-[18]. Episomal plasmids are used for reprogramming because they are easily introduced into and removed from target cells [94]. The downside of this method is the low transfection efficiency which requires multiple rounds of transfection. Alternatively, inefficiency of non-viral methods of reprogramming is being compensated by combinatorial approach wherein the donor cells are treated with small molecules that work by activation of endogenous pluripotency determining transcription factors, in conjunction with non-viral genetic manipulation [95].

As an alternative to ectopic transgene expression of pluripotency transcription factors, protocols for manipulation of microRNA (miRNA) profile for one or more specific miRNAs with role in pluripotency determining signalling pathways have been reported. miRNAs are short non-coding segments of RNA which regulate gene expression during various cellular processes including pluripotency and differentiation of stem cells [96]. Many recent studies have suggested the role of specific miRNAs in ESCs associated with pluripotency genes [97] [98]. Similar to the core set of transcription factors relevant to the differentiation status of ESCs, there is also a core set miRNAs associated with the differentiation status of ESCs including miRNA 302-367 and miRNA $290-295$. Interestingly, pluripotency determining transcription factors and the core set of ESC specific miRNA are intricately related to each other in terms of their functionality [99]. The premier usage of miRNA in reprogramming process is intended to enhance the rate and efficiency of iPSCs generation. Different miRNAs i.e., 200c, 302/367 cluster and 369s family have been effectively used for reprogramming of somatic cells but with low efficiency [100] [101]. Of this core set of miRNAs, over expression of micro-302 alone may drive the process of reprogramming of somatic cells [101]. An interesting aspect of miRNAs research in relation to reprogramming is maintenance of the epigenetic memory of the parent somatic cells [102].

\section{Epigenetics of iPSCs}

As discussed earlier, ESCs derived from the inner cell mass and iPSCs reprogrammed from somatic cells via transgenic expression of pluripotency determining transcription factors possess similar differentiation capacity. On molecular level, they significantly share gene expression as well as miRNA profile besides DNA methylation status. Nonetheless, both cell types exhibit differential set of genetic and epigenetic characteristics derived 
from their respective parent cells [103]. It is generally considered that the epigenome and the transcriptome of the parent cells that remain distant from the molecular events encompassing the reprogramming process are carried forward to the reprogrammed cells as part of the residual memory [104]. Indeed, pluripotent status and the subsequent differentiation characteristics of the pluripotent cells are associated with their epigenetic memory [105]. For example, immunogenicity of iPSCs is a continuation of the immunogenicity of their parent somatic cells as the immunogenicity-determining epigenome is sustained during the process of reprogramming [106]. Other studies have also highlighted that the derivative iPSCs carry forward the epigenetic memory of their respective parent cells thus defining it as arguably the key to control the efficiency of reprogramming process [103].

In terms of molecular signalling, epigenome influences the gene expression profile in a cell via enzymecatalysed reactions without altering the nucleotide sequence of the genome. In the context of iPSC, polycomb group of proteins (PcG) is a particularly important determinant of epigenetic inheritance by chromatin remodelling such that transcriptional repression ensues [107]. PcG is also implicated in the maintenance of undifferentiated self-renewal of stem cells, efficiency of reprogramming and molecular pathogenesis of cancer stem cells [103] [108]. At least two PcG complexes PRC1 (plycomb repressive complex-1) and PRC2 (plycomb repressive complex-2), either alone or synergistically, repress their target genes at the nucleosome level of the chromatin structure. The EZH1/2 subunit of the PRC2 is a histone methyltransferase that trimethylates the target genes on tyrosine 27 of histone 3 (H3K27). The trimethylated H3K27 (H3K27me3) is recognized by a subunit of the PRC1 called chromobix. Their complex leads to the recruitment of yet another subunit of the PRC1, RNF2/ RING1 ubiquitin ligase to attach a ubiquitin molecule to H2AK119 residue. These two epigenetic modifications make the chromatin three-dimensionally inaccessible to the transcriptional machinery. Pluripotency is preserved by maintaining a balance between transcription of pluripotency-related and lineage-specific genes with significant participation of PcG proteins to repress cell differentiation [103]. Notably however, the PcG proteins are unrelated to the pluripotency level in stem cells as they donot influence the expression levels of pluripotent markers, such as Oct4 and Nanog [108] [109].

\section{Pre-Clinical and Clinical Studies with Pluripotent Stem Cells and Potential Applications}

Both ESCs and iPSCs have been extensively characterized in experimental animal models for assessment of their therapeutic potential, disease modelling, and drug development (Table 5 \& Table 6). Mostly these studies provide ample proof of the concept that pluripotent stem cells, irrespective of their origin, can adopt functionally competent cell types belonging to all the three germ layers post-engraftment in experimental animal models. All these data are unambiguous in depicting the reparative potential of pluripotent stem cells. During two independent studies, mouse skeletal myoblast derived iPSCs as well as bone marrow derived iPSCs and their derivative cardiomyocytes effectively attenuated infarct size expansion in murine model of acute myocardial infarction [67] [68]. Fluorescence immunostaining for myogenic makers showed that the transplanted cells underwent myogenic differentiation at the site of the graft. Besides, blood vessel density was also increased in the cell transplanted hearts as compared to the control groups of animals. Nevertheless, one of the major findings in both the studies was that nearly $35 \%$ and $21 \%$ of the iPSCs transplanted animals developed cardiac tumours. These data raised serious safety concerns and a note of caution regarding clinical utility of iPSCs. However, use of cardiac progenitors instead of iPSCs during transplantation studies alleviated the teratogenic concerns. Despite these encouraging data with progenitor cells, both pluripotent stem cells and their progenitors warrant further investigation for safety and observable differences in transcriptome before regular clinical applications in the humans. It's imperative to appreciate that some of the therapeutic applications of iPSCs are being investigated in clinical trials; such as its application in treating macular degeneration [110].

The other two areas in which iPSC have been exploited are disease modelling and drug testing [111]. The strategy involves reprograming of patient-specific cells to pluripotency followed by their differentiation into the cell type that is involved in the disease process (Figure 2). These derivative cells are used as a model to decipher the evolution and molecular pathogenesis of the disease in question besides their use as a platform to test novel molecules with potential for drug development. Some examples of clinical studies currently underway are intended for developing disease specific iPSCs for use in vitro as disease models (Table 7). Spinal muscular dystrophy in this regard is a typical example of the most well-studied neurodegenerative genetic disorders which 
Table 5. Experimental and clinical studies using ESCs.

\begin{tabular}{|c|c|c|c|c|c|}
\hline & Experimental animal model & Cell Type/delivery & Important findings & Teratogenicity & References \\
\hline 1 & $\begin{array}{l}\text { Rat model of traumatic spinal } \\
\text { injury. Cell transplantation at } 9 \\
\text { days after injury. }\end{array}$ & $\begin{array}{l}\text { Mouse ESC derived neural cells/ } \\
\text { Direct transplantation at the } \\
\text { injured site. }\end{array}$ & $\begin{array}{l}\text { Survival of the transplanted cells } \\
\text { until } 5 \text { weeks of observation and } \\
\text { differentiation into astrocytes, } \\
\text { oligodendrocytes and neurons. }\end{array}$ & Not reported & $\begin{array}{l}\text { McDonald et } \\
\text { al., } 1999 .\end{array}$ \\
\hline 2 & SCID mice & $\begin{array}{l}\text { hESCs derived PECAM+ cells. } \\
\text { PLGA/PLLA patch or scaffold } \\
\text { based s.c implantation. }\end{array}$ & $\begin{array}{l}\text { New micro vessels with human } \\
\text { endothelial cells lining observed on } \\
\text { day } 7 \text { and } 14 \text { after engraftment. }\end{array}$ & Not reported & $\begin{array}{l}\text { Levenberg et } \\
\text { al., } 2002\end{array}$ \\
\hline 3 & $\begin{array}{l}\text { (MPTP-treated) monkeys, a } \\
\text { primate model for Parkinson's } \\
\text { disease }\end{array}$ & $\begin{array}{c}\text { Dopaminergic neurons from } \\
\text { monkey ESC derived } \\
\text { neurospheres treated with FGF20 } \\
\text { and FGF2 to for differentiation. } \\
\text { Direct injection into bilateral } \\
\text { putamen. }\end{array}$ & $\begin{array}{l}\text { Functional engraftment of } \\
\text { dopaminergic neurons to alleviate } \\
\text { MPTP-induced neurological } \\
\text { symptoms }\end{array}$ & Not reported & $\begin{array}{l}\text { Takagi et al., } \\
\quad 2005\end{array}$ \\
\hline 4 & $\begin{array}{l}\text { Athymic male rat heart model } \\
\text { of } \mathrm{I} / \mathrm{R} \text { injury. }\end{array}$ & $\begin{array}{l}\text { hESC derived cardiomyocytes } \\
\text { and treated with pro-survival } \\
\text { cocktail. Cell transplantation } 4 \\
\text { days after I/R injury by direct } \\
\text { intramyocardial injection. }\end{array}$ & $\begin{array}{l}\text { Engraftment and survival and } \\
\text { integration of the transplanted cells. } \\
\text { Significant attenuation of LV } \\
\text { remodeling and preservation of } \\
\text { cardiac function }\end{array}$ & Not reported & $\begin{array}{l}\text { Laflamme et } \\
\text { al., } 2005\end{array}$ \\
\hline 5 & $\begin{array}{c}\text { Mouse model of myogenesis } \\
\text { using cardiotoxin injection } \\
\text { alone or with } 25 \mathrm{~Gy} \\
\text { X-radiation. }\end{array}$ & $\begin{array}{l}\text { hESCs derived myogenic } \\
\text { precursors/IM injection. }\end{array}$ & $\begin{array}{l}\text { Myogenic differentiation of } \\
\text { xenotransplanted precursors. }\end{array}$ & $\begin{array}{c}\text { No evidence of } \\
\text { teratogenicity } \\
\text { until } 128 \text { days of } \\
\text { observation. }\end{array}$ & $\begin{array}{l}\text { Zheng et al., } \\
2006\end{array}$ \\
\hline 6 & $\begin{array}{l}\text { Rat model of myocardial } \\
\text { infarction by coronary artery } \\
\text { ligation with } \\
\text { immunosuppression. }\end{array}$ & $\begin{array}{l}\text { Direct intra-myocardial } \\
\text { injection of hESC derived } \\
\text { CMs and Non-CMs. }\end{array}$ & $\begin{array}{l}\text { Integration of hESCs derived CMs } \\
\text { with host CMs via gap junctions, } \\
\text { attenuated LV-remodeling and } \\
\text { improved LVFS. }\end{array}$ & $\begin{array}{l}\text { No teratomas } \\
\text { observed in hESC } \\
\text { derived CMs. }\end{array}$ & $\begin{array}{l}\text { Caspi et al., } \\
2007\end{array}$ \\
\hline 7 & $\begin{array}{l}\text { Porcine model of retinal stem } \\
\text { cell transplantation prepared by } \\
\text { treatment of iodoacetic acid to } \\
\text { eliminate photoreceptors }\end{array}$ & $\begin{array}{l}\text { Swine iPSCs derived Rho + rod } \\
\text { photoreceptors transplanted in to } \\
\text { sub-retinal space of pig eye. }\end{array}$ & $\begin{array}{c}\text { Successful engraftment and } \\
\text { integration of iPSCs-derived } \\
\text { Rho + photoreceptors into damaged } \\
\text { neural retina of pig. }\end{array}$ & Not reported & $\begin{array}{l}\text { Zhou et al., } \\
2011\end{array}$ \\
\hline 8 & $\begin{array}{l}\text { SCID/beige mice (deficient in } \\
\text { B and T lymphocytes and NK } \\
\text { cells) with alloxan induced } \\
\text { diabetes. Subcutaneous } \\
\text { implantation model. }\end{array}$ & $\begin{array}{l}\text { hESCs and their derivative } \\
\text { pancreatic islet progenitor cells } \\
\text { loaded into bilaminar } \\
\text { theracytes. Subcutaneous } \\
\text { implantation of the loaded } \\
\text { theracytes, }\end{array}$ & $\begin{array}{l}\text { Cells remain fully encapsulated. The } \\
\text { derivative pancreatic islet cells } \\
\text { secreted sufficient insulin to } \\
\text { alleviate diabetes at } 20 \text { weeks after } \\
\text { implantation. }\end{array}$ & Not reported & $\begin{array}{l}\text { Kirk et al., } \\
\quad 2014\end{array}$ \\
\hline 9 & $\begin{array}{l}\text { Macaque myocardial model of } \\
\text { ischemia followed by } \\
\text { reperfusion. }\end{array}$ & $\begin{array}{l}\text { hESCs derived CM } \\
\text { intramyocardial delivery }\end{array}$ & $\begin{array}{l}\text { Extensive re-muscularization of } \\
\text { myocardium and electro- } \\
\text { mechanical junctions between donor } \\
\text { and host myocytes. Non-fatal } \\
\text { arrhythmias. }\end{array}$ & $\begin{array}{l}\text { Not observed } \\
\text { until } 84 \text { days of } \\
\text { observation. }\end{array}$ & $\begin{array}{l}\text { Chong et al., } \\
2014\end{array}$ \\
\hline 10 & $\begin{array}{l}\text { Patients with Stargardt's } \\
\text { macular dystrophy and dry } \\
\text { age-related macular } \\
\text { degeneration }\end{array}$ & hESC & retinal pigmented epithelium (RPE) & $\begin{array}{l}\text { absent in an } \\
\text { observation } \\
\text { period of } 4 \\
\text { months }\end{array}$ & $\begin{array}{l}\text { Schwartz, } \\
2012\end{array}$ \\
\hline
\end{tabular}

CMs: Cardiomyocytes; hESCs: Human embryonic stem cells; IM: Intramuscular; I/R: Ischemia-reperfusion; LV: Left ventricle; LVFS: Left ventricular fractional shortening; MPTP: 1-methyl-4-phenyl-1,2,3,6-tetrahydropyridine; s.c.: Subcutaneous; SCID: severe combined immunodeficiency; 1. McDonald JW, Liu X-Z, Qu Y, Liu S, Mickey SK, Turetsky D, Gottlieb DI, Choi DW. Transplanted embryonic stem cells survive, differentiate and promote recovery in injured rat spinal cord. Nat Med, 5, 1410-1412 (1999). 2. Levenberg S, Golub JS, Amit M, Itskovitz-Eldor J, Langer R. Endothelial cells derived from human ESCs.2002;99(7) 4391-4396. 3. Takagi Y, Takahashi J, Saiki H, Morizane A, Hayashi T, Kishi Y, Fukuda H, Okamoto Y, Koyanagi M, Ideguchi M, Hayashi H, Imazato T, Kawasaki H, Suemori H, Omachi S, Iida H, Itoh N, Nakatsuji N, Sasai Y, Hashimoto N.Dopaminergic neurons generated from monkey ESCs function in a Parkinson primate model. J. Clin. Invest. 2005;115:102-109. 4. Laflamme MA, J. Gold, C. Xu, M. Hassanipour, E. Rosler, S. Police, C.E. Murry. Formation of human myocardium in the rat heart from human embryonic stem cells. Am. J. Pathol., 2005; 167(3):663-671. 5. Zheng JK, Wang Y, Karandikar A, Wang Q, Gai H, Liu AL, Peng C, Sheng HZ. Skeletal myogenesis by human ESCs. Cell Res. 2006; 16: 713-722. 6. Caspi O, Huber I, Kehat I, Habib M, Arbel G, Gepstein A, Yankelson L, Doron Aronson D, Beyar R, Gepstein L. Transplantation of Human Embryonic Stem Cell-Derived Cardiomyocytes Improves Myocardial Performance in Infarcted Rat Hearts. J Am CollCardiol 2007; 50: 1884-93. 7. Zhou L,Wang W, Liu Y, de Castro JF, Ezashi T, PrakashB, Telugu VL, Roberts RM, Kaplan HJ, Dean DC. Differentiation of swine ipsc into rod photoreceptors and their integration into the retina. Stem Cells. 2011 June; 29(6): 972-980. 8. Kirk K, Hao E, Lahmy R, Itkin-Ansari P. Human embryonic stem cell derived islet progenitors mature inside an encapsulation device without evidence of increased biomass or cell escape. Stem Cell Res., 2014; 12(3): 807-814. 9. Chong JH,'Xiulan Yang X, Don CW, Minami E, Liu Y-W, Weyers JJ, William M. Mahoney WM, Biber BV, Savannah M. Cook SM, Nathan J. Palpant NJ, Jay A. Gantz JA, James A. Fugate JA, Muskheli V, Gough CM, Vogel KW, Cliff A. Astley CA, CharlottHotchkiss CE, Audrey Baldessari A, Lil Pabon L, Reinecke H, Gill EA, Nelson V, Kiem H-P, Laflamme MA, Murry CE. Human embryonic-stem-cell-derived cardiomyocytes regenerate non-human primate hearts. 2014; 510: 273-277. 10. Schwartz SD, Hubschman J-P, Heilwell G, Franco-Cadenas V, Pan CK, Ostrik RM, Mickunas E, Gay R, Klimanskaya I, Lanza R. Embryonic stem cell trials for macular degeneration: a preliminary report. Lancet. 2012; 379(9817): 713-720. 
Table 6. Experimental animal studies using iPSCs and their derivative progenitor cells.

\begin{tabular}{|c|c|c|c|c|c|c|}
\hline \# & $\begin{array}{c}\text { Experimental animal } \\
\text { model }\end{array}$ & Cell type & $\begin{array}{l}\text { Route of } \\
\text { delivery }\end{array}$ & Important findings & Teratogenicity & Reference \\
\hline 1 & $\begin{array}{l}\text { Mice (adult wild-type } \\
\text { mice) }\end{array}$ & $\begin{array}{l}\text { hiPSC-derived } \\
\text { fibroblasts }\end{array}$ & $\begin{array}{l}\text { Direct injection } \\
\text { into the sub-retinal } \\
\text { space }\end{array}$ & $\begin{array}{l}\text { Photoreceptors } \\
\text { (retinal cells) }\end{array}$ & $\begin{array}{l}\text { No teratomas were } \\
\text { found following } \\
\text { transplantation }\end{array}$ & $\begin{array}{l}\text { Lamba et al., } \\
\quad 2010\end{array}$ \\
\hline 2 & $\begin{array}{l}\text { Mouse model of } \\
\text { contusive spinal cord } \\
\text { injury }\end{array}$ & $\begin{array}{l}\text { Safe iPSCs derived } \\
\text { neurospheres }\end{array}$ & $\begin{array}{l}\text { Direct injection } \\
\text { into lesion } \\
\text { epicenter }\end{array}$ & Neuronal differentiation & $\begin{array}{l}\text { Safe iPSCs derived } \\
\text { cells were } \\
\text { non-teratogenic }\end{array}$ & $\begin{array}{l}\text { Tsuji et al., } \\
2010\end{array}$ \\
\hline 3 & $\begin{array}{l}\text { Hind-limb ischemia } \\
\text { model of SCID mice by } \\
\text { femoral artery ligation }\end{array}$ & $\begin{array}{l}\text { hiPSC derived } \\
\text { endothelial cells }\end{array}$ & $\begin{array}{l}\text { Direct } \\
\text { intramuscular } \\
\text { injection }\end{array}$ & $\begin{array}{c}\text { Increased capillary } \\
\text { density and regional } \\
\text { perfusion }\end{array}$ & $\begin{array}{l}\text { No teratomas } \\
\text { reported }\end{array}$ & $\begin{array}{l}\text { Jalil et al., } \\
\quad 2011\end{array}$ \\
\hline 4 & $\begin{array}{l}\text { Mouse model of acute } \\
\text { coronary artery ligation }\end{array}$ & $\begin{array}{l}\text { Skeletal myoblast } \\
\text { derived iPSCs }\end{array}$ & $\begin{array}{c}\text { Direct } \\
\text { intra-myocardial } \\
\text { injection }\end{array}$ & $\begin{array}{l}\text { Angiomyogenesis with } \\
\text { preserved heart function }\end{array}$ & $\begin{array}{l}\text { 35\% animals with iPSCs } \\
\text { and no teratomas with } \\
\text { progenitor cells }\end{array}$ & $\begin{array}{l}\text { Ahmed et al., } \\
\quad 2012\end{array}$ \\
\hline
\end{tabular}
$5 \quad \begin{gathered}\text { Porcine model of } \\ \text { myocardial infarction }\end{gathered}$

Ischemic

6 cardiomyopathy with ameroid ring

7 Mouse model of acute coronary artery ligation

Mouse MSC-derived iPSCs or their derived cardiac progenitors.

Direct

intra-myocardial injection

Mice (7- to 8-week-old female nude mice and

8 immunodeficient mouse strains (nude, SCID,

NOD-SCID and NOG)
Dermal fibroblast derived hiPSC
Direct subcutaneous injection

Endothelial differentiation and neoangiogenesis

\section{Cardiomyogenesis with preserved LV remodeling and heart} function

Angiomyogenesis with preserved heart function
21\% animals developed teratomas with iPSCs and Buccini et al., no teratomas with progenitor cells 2012

None until 12 - 15 weeks Templin et al., after transplantation 2012

No teratogenicity during Kawamura et the course of studies al., 2012
Retinal pigment
epithelium

Negative after 15 months

Kanemura $\mathrm{H}$ et al., 2014

hiPSCs: human induced pluripotent stem cells; iPSCs: induced pluripotent stem cells; I/M: intramyocardial injection; MSC: mesenchymal stem cells; SCID: severe combined immunodeficiency. 1. Lamba D, McUsic A, Hirata R, et al. Generation, Purification and Transplantation of Photoreceptors Derived from Human Induced Pluripotent Stem Cells. Retrieved from http://www.ncbi.nlm.nih.gov/pmc/articles/PMC2808350/. 2. Tsuji O, Miura K, Okada Y, et al. Therapeutic potential of appropriately evaluated safe-induced pluripotent stem cells for spinal cord injury. Proc Nat AcadSci USA. 2010; 107: 12704-9. 3. Ahmed RP, Haider HK, Buccini S, Li L, Jiang S, Ashraf M. Reprogramming of skeletal myoblasts for induction of pluripotency for tumor-free cardiomyogenesis in the infarcted heart. Cir Res. 2011; 109: 60-70. 4. Jalil RA, Huang NF, Jame S, Lee J, Nguyen HN, Byers B, De A, Okogbaa J, Rollins M, Reijo-Pera R, Gambhir SJ, Cooke JP. Endothelial cells derived from human ipscs increase capillary density and improve perfusion in a mouse model of peripheral arterial disease. ArteriosclThrombVasc Biol. 2011; 31: e72-79. 5. Templin C, Zweigerdt R, Schwanke K, Olmer R, Ghadri JR, Maximilian Y. Emmert MY, Müller E, Küest SM, Cohrs S, Schibli R, Kronen P, Monika Hilbe M, Reinisch A, Strunk D, Haverich A, Hoerstrup S, Lüscher TF, Kaufmann PA, Landmesser U, Martin U. Transplantation and tracking of human-induced pluripotent stem cells in a pig model of myocardial infarction: Assessment of cell survival, engraftment, and distribution by hybrid single photon emission computed tomography/ computed tomography of sodium iodide symporter transgene expression. Circulation. 2012; 126: 430-439. 6. Kawamura M, Miyagawa S, Miki K, Saito A, Fukushima S, Higuchi T, Kawamura T, Kuratani T, Daimon T, Shimizu T, Okano T, Sawa Y. Feasibility, Safety, and Therapeutic Efficacy of Human Induced Pluripotent Stem Cell-Derived Cardiomyocyte Sheets in a Porcine Ischemic Cardiomyopathy Model. Circulation. 2012; 126 [suppl 1]: S29-S37. 7. Stephanie Buccini S, HaiderHKh, Ahmed RPH, Jiang S. Cardiac progenitors derived from reprogrammed mesenchymal stem cells contribute to angiomyogenic repair of the infarcted heart.Basic Res Cardiol. 2012; 107: 301. 8. Kanemura H, Nishishita N, Shikamura M, et al. Tumorigenicity studies of induced pluripotent stem cell (iPSC)-derived retinal pigment epithelium (RPE) for the treatment of age-related macular degeneration. Retrieved from http://journals.plos.org/plosone/article?id=10.1371/journal.pone.0085336\#s4.

lead to infant mortality [112]. Prior to the use of patient specific iPSC derived motor neurones, patient derived fibroblasts were mainly used to study the disease process. Given that motor neurones have specific features not shared by fibroblasts, the use of iPSC derived disease specific motor neurones provide superior and more relevant ex vivo disease model [113]. Since the publication of these data, similar studies have also been reported for both haematological and non-haematological disorders [114]. The use of iPSCs for generation of disease specific models carries several advantages. Firstly, in most cases, the availability of the desired cell types from the patient required for use as a model remains problematic. iPSCs have solved this problem by providing an unlimited 


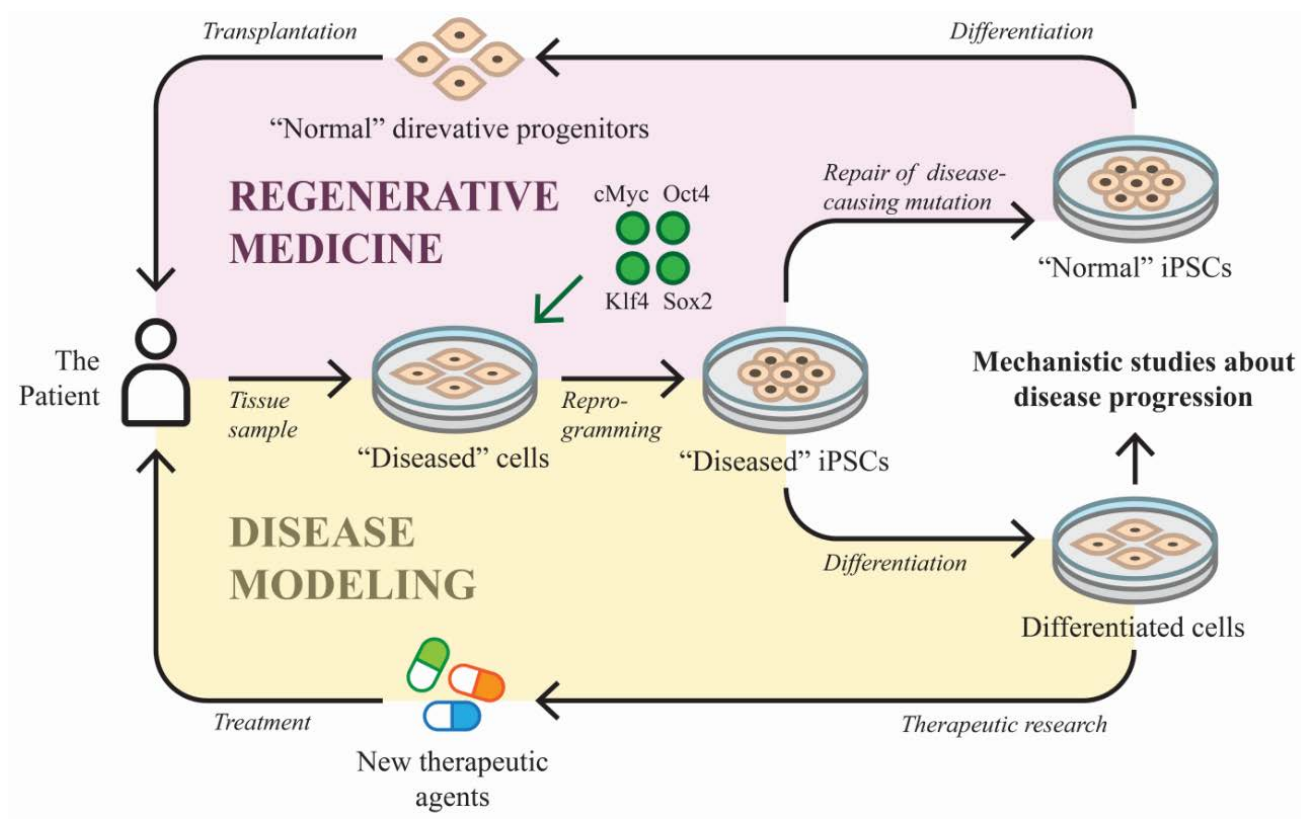

Figure 2. Potential applications of iPSCs.

Table 7. Clinical studies involving iPSCs generated from the somatic cells donated by the patients with different pathological disorders. The prime objective of these studies is to study the disease mechanism and drug research rather than regenerative or reparative use in the human subjects.

\begin{tabular}{|c|c|c|c|c|c|c|}
\hline $\begin{array}{l}\text { Clinical } \\
\text { Trials.gov } \\
\text { Identifier }\end{array}$ & $\begin{array}{l}\text { Location and } \\
\text { Investigator }\end{array}$ & Title of the study & Purpose & Start Date & $\begin{array}{c}\text { Completion } \\
\text { date }\end{array}$ & $\begin{array}{c}\text { Cells } \\
\text { involved }\end{array}$ \\
\hline NCT01943383 & $\begin{array}{l}\text { Julie A Johnson, Pharm } \\
\text { D. University of } \\
\text { Florida, USA }\end{array}$ & $\begin{array}{c}\text { Pharmacogenomic } \\
\text { evaluation of } \\
\text { antihypertensive responses } \\
\text { in iPSC study (PEAR-iPSC) }\end{array}$ & $\begin{array}{l}\text { To study the variation in } \\
\text { responsiveness of antihypertensive } \\
\text { drug therapy in different } \\
\text { individuals. }\end{array}$ & $\begin{array}{c}\text { August } \\
2013\end{array}$ & $\begin{array}{l}\text { October } \\
2016\end{array}$ & iPSCs \\
\hline NCT02246491 & $\begin{array}{l}\text { Sonia Franco, MD. } \\
\text { Sidney Kimmel } \\
\text { Comprehensive Cancer } \\
\text { Center, John Hopkins, } \\
\text { USA }\end{array}$ & $\begin{array}{l}\text { iPSC-based approaches for } \\
\text { modelling and treating } \\
\text { Ataxia-Telangiectasia }\end{array}$ & $\begin{array}{c}\text { To understand the disease } \\
\text { mechanism of } \\
\text { Ataxia-Telangiectasia (A-T) using } \\
\text { patient fibroblast derived iPSC in } \\
\text { vitro. }\end{array}$ & $\begin{array}{c}\text { October } \\
2014\end{array}$ & $\begin{array}{c}\text { October } \\
2017\end{array}$ & iPSCs \\
\hline NCT02193724 & $\begin{array}{l}\text { Rachel C. Brennan, MD } \\
\text { St. Jude Children’s } \\
\text { Research Hospital } \\
\text { (University of } \\
\text { Wisconsin, Madison, } \\
\text { USA: collaborator) }\end{array}$ & $\begin{array}{l}\text { Feasibility, validation and } \\
\text { differentiation of iPSC } \\
\text { produced from patients with } \\
\text { heritable retinoblastoma }\end{array}$ & $\begin{array}{l}\text { To establish the feasibility of } \\
\text { producing iPSCs from } \\
\text { retinoblastoma patients with } \\
\text { germline RB1 mutations, validate } \\
\text { the derivative cells and differentiate } \\
\text { them into retina as a model of the } \\
\text { initiation of retinoblastoma in the } \\
\text { developing retina. }\end{array}$ & $\begin{array}{c}\text { October } \\
2014\end{array}$ & April 2017 & iPSCs \\
\hline NCT02056613 & $\begin{array}{c}\text { David F Stroncek, } \\
\text { M.DNational Institutes } \\
\text { of Health Clinical } \\
\text { Centre, USA }\end{array}$ & $\begin{array}{l}\text { Blood collection from } \\
\text { healthy volunteers and } \\
\text { patients for the production } \\
\text { of clinical grade iPSC } \\
\text { products. }\end{array}$ & $\begin{array}{l}\text { To develop new methods to make } \\
\text { iPSCs; to identify better ways to } \\
\text { collect, produce, and grow them; } \\
\text { and to make an iPSC bank. }\end{array}$ & $\begin{array}{c}\text { January } \\
2014\end{array}$ & $\begin{array}{l}\text { October } \\
2018\end{array}$ & iPSCs \\
\hline NCT00874783 & $\begin{array}{c}\text { Benjamin E Reubinoff, } \\
\text { MD., PhD. } \\
\text { Hadassah Medical } \\
\text { Organization, USA }\end{array}$ & $\begin{array}{l}\text { Derivation of iPSCs from } \\
\text { somatic cells donated by } \\
\text { patients with neurological } \\
\text { diseases for the study of the } \\
\text { pathogenesis of the disor- } \\
\text { ders and development of } \\
\text { novel therapies. }\end{array}$ & $\begin{array}{l}\text { The major goal of the project is to } \\
\text { develop human iPSCs from cell } \\
\text { cultures from skin biopsies or the } \\
\text { patient's hair for modelling } \\
\text { diseases and drug discovery and for } \\
\text { developing the technology that may } \\
\text { eventually allow the use of iPS } \\
\text { cells for future } \\
\text { transplantation therapy. }\end{array}$ & $\begin{array}{c}\text { April, } \\
2009\end{array}$ & $\begin{array}{c}\text { December, } \\
2018\end{array}$ & iPSCs \\
\hline
\end{tabular}

Source: https://clinicaltrials.gov/ct2/results?term=Induced+pluripotent+stem+cells\&Search=Search. 
continuous source of the cells in question. Secondly, iPSC derivation of cells for a disease model allows temporal observation of the course of disease process thus enhancing the complete understanding of the molecular pathogenesis of the disease in question. Despite these advantages, this "disease in a petri dish approach" also has many limitations. Although the approach ensures continuum of disease specific cells for study, it necessitates disease specific iPSC generation from multiple patients to cover full span of the possible phenotypic variations from differing levels of the severity of the disease. Additionally, differentiation of disease specific iPSCs to obtain the disease specific cells necessitates optimization such that the derivative cells more closely resemble the cells present in the patient during the natural course of the disease process. Moreover, such applications may be restricted to monogenetic diseases only and would require in-depth research for more complex multifactorial diseases. Despite these limitations, iPSC derived disease specific cells are significant addition to the ex vivo models for pharmacological studies and toxicity assessment of novel compound libraries for high throughput screening during drug development [115]-[117].

\section{Conclusion}

As discussed earlier, iPSCs have multiple potential applications that can be classified into three main areas of interest: therapeutic applications, disease modelling, and drug testing. Despite encouraging results, the potential application of iPSC in tissue transplantation and repairing disease-causing mutations by homologous recombination has yet to show its effectiveness in routine clinical practice. While iPSCs have overcome the issues encountered by their counterpart ESCs and other stem cell types including immune tolerance and ethical controversies, the safety of its use in human remains a major impediment. Some of the safety concerns imply their potential tumorigenicity and the observable differences in the transcriptome of iPSCs and ESCs as discussed earlier. It is worthwhile to appreciate that iPSCs have entered into clinical trials for reparation and restitution of diseased tissues as the prime objective such as their application for the treatment of macular degeneration. Although the trial has been suspended on account of failure of the cells to pass genetic validation for the second patient enrolled in the study, this is a big leap that has created new hope for the use of pluripotent stem cells.

\section{References}

[1] Daar, A.S. and Greenwood, H.L. (2007) A Proposed Definition of Regenerative Medicine. Journal of Tissue Engineering and Regenerative Medicine, 1, 179-184. http://dx.doi.org/10.1002/term.20

[2] Handberg-Thorsager, M., Fernandez, E. and Salo, E. (2008) Stem Cells and Regeneration in Planarians. Frontiers in Bioscience, 13, 6374-6394. http://dx.doi.org/10.2741/3160

[3] Bajada, S., Mazakova, I., Richardson, J.B. and Ashammakhi, N. (2008) Updates on Stem Cells and Their Applications in Regenerative Medicine. Journal of Tissue Engineering and Regenerative Medicine, 2, 169-183. http://dx.doi.org/10.1002/term.83

[4] David, B.G., Okamoto, K., Kakizuka, T., Ichimura, T., Watanabe, T.M. and Fujita, H. (2015) Gene Dynamics of Core Transcription Factors for Pluripotency in Embryonic Stem Cells. Journal of Bioscience and Bioengineering, 119, 406409. http://dx.doi.org/10.1016/j.jbiosc.2014.09.011

[5] Alison, M.R., Poulsom, R., Forbes, S. and Wright, N.A. (2002) An Introduction to Stem Cells. Journal of Pathology, 197, 419-423. http://dx.doi.org/10.1002/path.1187

[6] Kumar, R., Sharma, A., Pattnaik, A.K. and Varadwaj, P.K. (2010) Stem Cells: An Overview with Respect to Cardiovascular and Renal Disease. Journal of Natural Science, Biology and Medicine, 1, 43-52. http://dx.doi.org/10.4103/0976-9668.71674

[7] Jahagirdar, B.N. and Verfaillie, C.M. (2005) Multipotent Adult Progenitor Cell and Stem Cell Plasticity. Stem Cell Reviews, 1, 53-59. http://dx.doi.org/10.1385/SCR:1:1:053

[8] Takahashi, K. and Yamanaka, S. (2006) Induction of Pluripotent Stem Cells from Mouse Embryonic and Adult Fibroblast Cultures by Defined Factors. Cell, 126, 663-676. http://dx.doi.org/10.1016/j.cell.2006.07.024

[9] Yu, J., Vodyanik, M.A., Smuga-Otto, K., et al. (2007) Induced Pluripotent Stem Cell Lines Derived from Human Somatic Cells. Science, 318, 1917-1920. http://dx.doi.org/10.1126/science.1151526

[10] Nakagawa, M., Koyanagi, M., Tanabe, K., et al. (2008) Generation of Induced Pluripotent Stem Cells without Myc from Mouse and Human Fibroblasts. Nature Biotechnology, 26, 101-106. http://dx.doi.org/10.1038/nbt1374

[11] Kim, J.B., Zaehres, H., Wu, G., et al. (2008) Pluripotent Stem Cells Induced from Adult Neural Stem Cells by Reprogramming with Two Factors. Nature, 454, 646-650. http://dx.doi.org/10.1038/nature07061 
[12] Hester, M.E., Song, S., Miranda, C.J., Eagle, A., Schwartz, P.H. and Kaspar, B.K. (2009) Two Factor Reprogramming of Human Neural Stem Cells into Pluripotency. PLoS ONE, 4, e7044. http://dx.doi.org/10.1371/journal.pone.0007044

[13] Nemajerova, A., Kim, S.Y., Petrenko, O. and Moll, U.M. (2012) Two-Factor Reprogramming of Somatic Cells to Pluripotent Stem Cells Reveals Partial Functional Redundancy of Sox2 and Klf4. Cell Death \& Differentiation, 19, 1268-1276. http://dx.doi.org/10.1038/cdd.2012.45

[14] Okita, K., Nakagawa, M., Hyenjong, H., Ichisaka, T. and Yamanaka, S. (2008) Generation of Mouse Induced Pluripotent Stem Cells without Viral Vectors. Science, 322, 949-953. http://dx.doi.org/10.1126/science.1164270

[15] Zhou, W. and Freed, C.R. (2009) Adenoviral Gene Delivery Can Reprogram Human Fibroblasts to Induced Pluripotent Stem Cells. Stem Cells (Dayton, Ohio), 27, 2667-2674. http://dx.doi.org/10.1002/stem.201

[16] Woltjen, K., Michael, I.P., Mohseni, P., et al. (2009) piggyBac Transposition Reprograms Fibroblasts to Induced Pluripotent Stem Cells. Nature, 458, 766-770. http://dx.doi.org/10.1038/nature07863

[17] Fontes, A., Macarthur, C.C., Lieu, P.T. and Vemuri, M.C. (2013) Generation of Human-Induced Pluripotent Stem Cells (hiPSCs) Using Episomal Vectors on Defined Essential $8^{\mathrm{TM}}$ Medium Conditions. Methods in Molecular Biology (Clifton, NJ.), 997, 57-72. http://dx.doi.org/10.1007/978-1-62703-348-0_6

[18] Hu, K. and Slukvin, I. (2013) Generation of Transgene-Free iPSC Lines from Human Normal and Neoplastic Blood Cells Using Episomal Vectors. Methods in Molecular Biology (Clifton, NJ.), 997, 163-176. http://dx.doi.org/10.1007/978-1-62703-348-0 13

[19] Meraviglia, V., Zanon, A., Lavdas, A.A., et al. (2015) Generation of Induced Pluripotent Stem Cells from Frozen Buffy Coats Using Non-Integrating Episomal Plasmids. Journal of Visualized Experiments, 100, e52885. http://dx.doi.org/10.3791/52885

[20] Hoffman, L.M. and Carpenter, M.K. (2005) Characterization and Culture of Human Embryonic Stem Cells. Nature Biotechnology, 23, 699-708. http://dx.doi.org/10.1038/nbt1102

[21] Martin, G.R. (1981) Isolation of a Pluripotent Cell Line from Early Mouse Embryos Cultured in Medium Conditioned by Teratocarcinoma Stem Cells. Proceedings of the National Academy of Sciences of the United States of America, 78, 7634-7638. http://dx.doi.org/10.1073/pnas.78.12.7634

[22] Thomson, J.A., Itskovitz-Eldor, J., Shapiro, S.S., et al. (1998) Embryonic Stem Cell Lines Derived from Human Blastocysts. Science, 282, 1145-1147. http://dx.doi.org/10.1126/science.282.5391.1145

[23] Cowan, C.A., Klimanskaya, I., McMahon, J., et al. (2004) Derivation of Embryonic Stem-Cell Lines from Human Blastocysts. The New England Journal of Medicine, 350, 1353-1356. http://dx.doi.org/10.1056/NEJMsr040330

[24] Ström, S., Inzunza, J., Grinnemo, K.-H., et al. (2007) Mechanical Isolation of the Inner Cell Mass Is Effective In Derivation of New Human Embryonic Stem Cell Lines. Human Reproduction, 22, 3051-3058. http://dx.doi.org/10.1093/humrep/dem335

[25] Draper, J.S., Smith, K., Gokhale, P., et al. (2004) Recurrent Gain of Chromosomes 17q and 12 in Cultured Human Embryonic Stem Cells. Nature Biotechnology, 22, 53-54. http://dx.doi.org/10.1038/nbt922

[26] Brimble, S.N., Zeng, X., Weiler, D.A., et al. (2004) Karyotypic Stability, Genotyping, Differentiation, Feeder-Free Maintenance, and Gene Expression Sampling in Three Human Embryonic Stem Cell Lines Derived Prior to August 9, 2001. Stem Cells and Development, 13, 585-597. http://dx.doi.org/10.1089/scd.2004.13.585

[27] Mitalipova, M.M., Rao, R.R., Hoyer, D.M., et al. (2005) Preserving the Genetic Integrity of Human Embryonic Stem Cells. Nature Biotechnology, 23, 19-20. http://dx.doi.org/10.1038/nbt0105-19

[28] Turetsky, T., Aizenman, E., Gil, Y., et al. (2008) Laser-Assisted Derivation of Human Embryonic Stem Cell Lines from IVF Embryos after Preimplantation Genetic Diagnosis. Human Reproduction, 23, 46-53. http://dx.doi.org/10.1093/humrep/dem351

[29] Ginis, I., Luo, Y., Miura, T., et al. (2004) Differences between Human and Mouse Embryonic Stem Cells. Developmental Biology, 269, 360-380. http://dx.doi.org/10.1016/j.ydbio.2003.12.034

[30] Burdon, T., Smith, A. and Savatier, P. (2002) Signalling, Cell Cycle and Pluripotency in Embryonic Stem Cells. Trends in Cell Biology, 12, 432-438. http://dx.doi.org/10.1016/S0962-8924(02)02352-8

[31] Dani, C., Chambers, I., Johnstone, S., et al. (1998) Paracrine Induction of Stem Cell Renewal by LIF-Deficient Cells: A New ES Cell Regulatory Pathway. Developmental Biology, 203, 149-162. http://dx.doi.org/10.1006/dbio.1998.9026

[32] Chambers, I., Colby, D., Robertson, M., et al. (2003) Functional Expression Cloning of Nanog, a Pluripotency Sustaining Factor in Embryonic Stem Cells. Cell, 113, 643-655. http://dx.doi.org/10.1016/S0092-8674(03)00392-1

[33] Blancas, A.A., Chen, C.-S., Stolberg, S. and McCloskey, K.E. (2011) Adhesive Forces in Embryonic Stem Cell Cultures. Cell Adhesion \& Migration, 5, 472-479. http://dx.doi.org/10.4161/cam.5.6.18270

[34] Amit, M., Margulets, V., Segev, H., et al. (2003) Human Feeder Layers for Human Embryonic Stem Cells. Biology of Reproduction, 68, 2150-2156. http://dx.doi.org/10.1095/biolreprod.102.012583 
[35] Richards, M., Fong, C.-Y., Chan, W.-K., Wong, P.-C. and Bongso, A. (2002) Human Feeders Support Prolonged Undifferentiated Growth of Human Inner Cell Masses and Embryonic Stem Cells. Nature Biotechnology, 20, 933-936. http://dx.doi.org/10.1038/nbt726

[36] Miyamoto, K., Hayashi, K., Suzuki, T., et al. (2004) Human Placenta Feeder Layers Support Undifferentiated Growth of Primate Embryonic Stem Cells. Stem Cells, 22, 433-440. http://dx.doi.org/10.1634/stemcells.22-4-433

[37] Cheng, L., Hammond, H., Ye, Z., Zhan, X. and Dravid, G. (2003) Human Adult Marrow Cells Support Prolonged Expansion of Human Embryonic Stem Cells in Culture. Stem Cells, 21, 131-142. http://dx.doi.org/10.1634/stemcells.21-2-131

[38] Bongso, A., Fong, C.-Y., Ng, S.-C. and Ratnam, S. (1994) Fertilization and Early Embryology: Isolation and Culture of Inner Cell Mass Cells from Human Blastocysts. Human Reproduction, 9, 2110-2117.

[39] Gerecht, S., Burdick, J.A., Ferreira, L.S., Townsend, S.A., Langer, R. and Vunjak-Novakovic, G. (2007) Hyaluronic Acid Hydrogel for Controlled Self-Renewal and Differentiation of Human Embryonic Stem Cells. Proceedings of the National Academy of Sciences of the United States of America, 104, 11298-11303. http://dx.doi.org/10.1073/pnas.0703723104

[40] Kristensen, D.M., Kalisz, M. and Nielsen, J.H. (2005) Cytokine Signalling in Embryonic Stem Cells. APMIS, 113, 756-772. http://dx.doi.org/10.1111/j.1600-0463.2005.apm_391.x

[41] Dahéron, L., Opitz, S.L., Zaehres, H., et al. (2004) LIF/STAT3 Signaling Fails to Maintain Self-Renewal of Human Embryonic Stem Cells. Stem Cells, 22, 770-778. http://dx.doi.org/10.1634/stemcells.22-5-770

[42] Suter, D.M. and Krause, K.-H. (2008) Neural Commitment of Embryonic Stem Cells: Molecules, Pathways and Potential for Cell Therapy. The Journal of Pathology, 215, 355-368. http://dx.doi.org/10.1002/path.2380

[43] Parsons, X.H. (2012) MicroRNA Profiling Reveals Distinct Mechanisms Governing Cardiac and Neural Lineage-Specification of Pluripotent Human Embryonic Stem Cells. Journal of Stem Cell Research \& Therapy, 2, 124. http://www.ncbi.nlm.nih.gov/pmc/articles/PMC3554249/

[44] Parsons, X.H., Teng, Y.D., Parsons, J.F., Snyder, E.Y., Smotrich, D.B. and Moore, D.A. (2011) Efficient Derivation of Human Cardiac Precursors and Cardiomyocytes from Pluripotent Human Embryonic Stem Cells with Small Molecule Induction. Journal of Visualized Experiments (JoVE), No. 57, e3274.

[45] Vassena, R., Eguizabal, C., Heindryckx, B., et al. (2015) Stem Cells in Reproductive Medicine: Ready for the Patient? Human Reproduction, 30, 2014-2021. http://dx.doi.org/10.1093/humrep/dev181

[46] Lo, B. and Parham, L. (2009) Ethical Issues in Stem Cell Research. Endocrine Reviews, 30, 204-213. http://dx.doi.org/10.1210/er.2008-0031

[47] Baker, D.E.C., Harrison, N.J., Maltby, E., et al. (2007) Adaptation to Culture of Human Embryonic Stem Cells and Oncogenesis in Vivo. Nature Biotechnology, 25, 207-215. http://dx.doi.org/10.1038/nbt1285

[48] Tan, Y., Ooi, S. and Wang, L. (2014) Immunogenicity and Tumorigenicity of Pluripotent Stem Cells and Their Derivatives: Genetic and Epigenetic Perspectives. Current Stem Cell Research \& Therapy, 9, 63-72. http://dx.doi.org/10.2174/1574888X113086660068

[49] Swijnenburg, R.-J., Tanaka, M., Vogel, H., et al. (2005) Embryonic Stem Cell Immunogenicity Increases upon Differentiation after Transplantation into Ischemic Myocardium. Circulation, 112, I166-I172.

[50] Ladhoff, J., Bader, M., Brösel, S., et al. (2009) Low Immunogenicity of Endothelial Derivatives from Rat Embryonic Stem Cell-Like Cells. Cell Research, 19, 507-518. http://dx.doi.org/10.1038/cr.2009.21

[51] Sánchez, L., Gutierrez-Aranda, I., Ligero, G., et al. (2011) Enrichment of Human ESC-Derived Multipotent Mesenchymal Stem Cells with Immunosuppressive and Anti-Inflammatory Properties Capable to Protect Against Experimental Inflammatory Bowel Disease. Stem Cells, 29, 251-262. http://dx.doi.org/10.1002/stem.569

[52] Lee, A.S., Tang, C., Rao, M.S., Weissman, I.L. and Wu, J.C. (2013) Tumorigenicity as a Clinical Hurdle for Pluripotent Stem Cell Therapies. Nature Medicine, 19, 998-1004. http://dx.doi.org/10.1038/nm.3267

[53] Knoepfler, P.S. (2009) Deconstructing Stem Cell Tumorigenicity: A Roadmap to Safe Regenerative Medicine. Stem Cells, 27, 1050-1056. http://dx.doi.org/10.1002/stem.37

[54] Murugan, V. (2009) Embryonic Stem Cell Research: A Decade of Debate from Bush to Obama. Yale Journal of Biology and Medicine, 82, 101-103.

[55] Kington, R.S. (2009) Guidelines on Human Stem Cell Research. Stem Cell Information, NIH.

[56] Puri, M.C. and Nagy, A. (2012) Concise Review: Embryonic Stem Cells versus Induced Pluripotent Stem Cells: The Game Is on. Stem Cells, 30, 10-14. http://dx.doi.org/10.1002/stem.788

[57] Wilmut, I., Schnieke, A.E., McWhir, J., Kind, A.J. and Campbell, K.H.S. (1997) Viable Offspring Derived from Fetal and Adult Mammalian Cells. Nature, 385, 810-813. http://dx.doi.org/10.1038/385810a0 
[58] Polo, J.M., Liu, S., Figueroa, M.E., et al. (2010) Cell Type of Origin Influences the Molecular and Functional Properties of Mouse Induced Pluripotent Stem Cells. Nature Biotechnology, 28, 848-855. http://dx.doi.org/10.1038/nbt.1667

[59] Chin, M.H., Mason, M.J., Xie, W., et al. (2009) Induced Pluripotent Stem Cells and Embryonic Stem Cells Are Distinguished by Gene Expression Signatures. Cell Stem Cell, 5, 111-123. http://dx.doi.org/10.1016/j.stem.2009.06.008

[60] Zhao, T., Zhang, Z.-N., Rong, Z. and Xu, Y. (2011) Immunogenicity of Induced Pluripotent Stem Cells. Nature, 474, 212-215. http://dx.doi.org/10.1038/nature10135

[61] Takahashi, K., Tanabe, K., Ohnuki, M., et al. (2007) Induction of Pluripotent Stem Cells from Adult Human Fibroblasts by Defined Factors. Cell, 131, 861-872. http://dx.doi.org/10.1016/j.cell.2007.11.019

[62] Stadtfeld, M., Nagaya, M., Utikal, J., Weir, G. and Hochedlinger, K. (2008) Induced Pluripotent Stem Cells Generated without Viral Integration. Science, 322, 945-949. http://dx.doi.org/10.1126/science.1162494

[63] Yamanaka, S. (2009) Elite and Stochastic Models for Induced Pluripotent Stem Cell Generation. Nature, 460, 49-52. http://dx.doi.org/10.1038/nature08180

[64] Tamaoki, N., Takahashi, K., Tanaka, T., et al. (2010) Dental Pulp Cells for Induced Pluripotent Stem Cell Banking. Journal of Dental Research, 89, 773-778. http://dx.doi.org/10.1177/0022034510366846

[65] Loh, Y.-H., Agarwal, S., Park, I.-H., et al. (2009) Generation of Induced Pluripotent Stem Cells from Human Blood. Blood, 113, 5476-5479. http://dx.doi.org/10.1182/blood-2009-02-204800

[66] Seki, T., Yuasa, S., Oda, M., et al. (2010) Generation of Induced Pluripotent Stem Cells from Human Terminally Differentiated Circulating T Cells. Cell Stem Cell, 7, 11-14. http://dx.doi.org/10.1016/j.stem.2010.06.003

[67] Buccini, S., Haider, K.H., Ahmed, R.P.H., Jiang, S. and Ashraf, M. (2012) Cardiac Progenitors Derived from Reprogrammed Mesenchymal Stem Cells Contribute to Angiomyogenic Repair of the Infarcted Heart. Basic Research in Cardiology, 107, 301. http://dx.doi.org/10.1007/s00395-012-0301-5

[68] Ahmed, R.P.H., Haider, H.K., Buccini, S., Li, L., Jiang, S. and Ashraf, M. (2011) Reprogramming of Skeletal Myoblasts for Induction of Pluripotency for Tumor-Free Cardiomyogenesis in the Infarcted Heart. Circulation Research, 109, 60-70. http://dx.doi.org/10.1161/CIRCRESAHA.110.240010

[69] Wakao, S., Kitada, M., Kuroda, Y., et al. (2011) Multilineage-Differentiating Stress-Enduring (Muse) Cells Are a Primary Source of Induced Pluripotent Stem Cells in Human Fibroblasts. Proceedings of the National Academy of Sciences of the United States of America, 108, 9875-9880. http://dx.doi.org/10.1073/pnas.1100816108

[70] Li, Y., Shen, Z., Shelat, H. and Geng, Y.-J. (2013) Reprogramming Somatic Cells to Pluripotency: A Fresh Look at Yamanaka’s Model. Cell Cycle, 12, 3594-3598. http://dx.doi.org/10.4161/cc.26952

[71] Buganim, Y., Faddah, D.A., Cheng, A.W., et al. (2012) Single-Cell Expression Analyses during Cellular Reprogramming Reveal an Early Stochastic and a Late Hierarchic Phase. Cell, 150, 1209-1222. http://dx.doi.org/10.1016/j.cell.2012.08.023

[72] Yamanaka, S. (2007) Strategies and New Developments in the Generation of Patient-Specific Pluripotent Stem Cells. Cell Stem Cell, 1, 39-49. http://dx.doi.org/10.1016/j.stem.2007.05.012

[73] Wernig, M., Meissner, A., Foreman, R., et al. (2007) In Vitro Reprogramming of Fibroblasts into a Pluripotent ESCell-Like State. Nature, 448, 318-324. http://dx.doi.org/10.1038/nature05944

[74] Wernig, M., Meissner, A., Cassady, J.P. and Jaenisch, R. (2008) c-Myc Is Dispensable for Direct Reprogramming of Mouse Fibroblasts. Cell Stem Cell, 2, 10-12. http://dx.doi.org/10.1016/j.stem.2007.12.001

[75] Huangfu, D., Osafune, K., Maehr, R., et al. (2008) Induction of Pluripotent Stem Cells from Primary Human Fibroblasts with Only Oct4 and Sox2. Nature Biotechnology, 26, 1269-1275. http://dx.doi.org/10.1038/nbt.1502

[76] Kim, J.B., Greber, B., Araúzo-Bravo, M.J., et al. (2009) Direct Reprogramming of Human Neural Stem Cells by OCT4. Nature, 461, 649-653. http://dx.doi.org/10.1038/nature08436

[77] Tsai, S.-Y., Bouwman, B.A., Ang, Y.-S., et al. (2011) Single Transcription Factor Reprogramming of Hair Follicle Dermal Papilla Cells to Induced Pluripotent Stem Cells. Stem Cells, 29, 964-971. http://dx.doi.org/10.1002/stem.649

[78] Zhu, S., Li, W., Zhou, H., et al. (2010) Reprogramming of Human Primary Somatic Cells by OCT4 and Chemical Compounds. Cell Stem Cell, 7, 651-655. http://dx.doi.org/10.1016/j.stem.2010.11.015

[79] Lyssiotis, C.A., Foreman, R.K., Staerk, J., et al. (2009) Reprogramming of Murine Fibroblasts to Induced Pluripotent Stem Cells with Chemical Complementation of Klf4. Proceedings of the National Academy of Sciences of the United States of America, 106, 8912-8917. http://dx.doi.org/10.1073/pnas.0903860106

[80] Feng, B., Ng, J.-H., Heng, J.-C.D. and Ng, H.-H. (2009) Molecules That Promote or Enhance Reprogramming of Somatic Cells to Induced Pluripotent Stem Cells. Cell Stem Cell, 4, 301-312. http://dx.doi.org/10.1016/j.stem.2009.03.005

[81] Yamaguchi, T., Hamanaka, S. and Nakauchi, H. (2014) The Generation and Maintenance of Rat Induced Pluripotent 
Stem Cells. In: Kioussi, C., Ed., Stem Cells and Tissue Repair. Methods in Molecular Biology, Vol. 1210, Springer, New York, 143-150. http://dx.doi.org/10.1007/978-1-4939-1435-7_11

[82] Merkl, C., Saalfrank, A., Riesen, N., et al. (2013) Efficient Generation of Rat Induced Pluripotent Stem Cells Using a Non-Viral Inducible Vector. PLoS ONE, 8, e55170. http://dx.doi.org/10.1371/journal.pone.0055170

[83] Fang, R., Liu, K., Zhao, Y., et al. (2014) Generation of Naive Induced Pluripotent Stem Cells from Rhesus Monkey Fibroblasts. Cell Stem Cell, 15, 488-496. http://dx.doi.org/10.1016/j.stem.2014.09.004

[84] Wu, Z., Chen, J., Ren, J., et al. (2009) Generation of Pig Induced Pluripotent Stem Cells with a Drug-Inducible System. Journal of Molecular Cell Biology, 1, 46-54. http://dx.doi.org/10.1093/jmcb/mjp003

[85] Ezashi, T., Telugu, B.P.V.L., Alexenko, A.P., Sachdev, S., Sinha, S. and Roberts, R.M. (2009) Derivation of Induced Pluripotent Stem Cells from Pig Somatic Cells. Proceedings of the National Academy of Sciences of the United States of America, 106, 10993-10998. http://dx.doi.org/10.1073/pnas.0905284106

[86] Park, I.-H., Zhao, R., West, J.A., et al. (2008) Reprogramming of Human Somatic Cells to Pluripotency with Defined Factors. Nature, 451, 141-146. http://dx.doi.org/10.1038/nature06534

[87] Aasen, T., Raya, A., Barrero, M.J., et al. (2008) Efficient and Rapid Generation of Induced Pluripotent Stem Cells from Human Keratinocytes. Nature Biotechnology, 26, 1276-1284. http://dx.doi.org/10.1038/nbt.1503

[88] Aoi, T., Yae, K., Nakagawa, M., et al. (2008) Generation of Pluripotent Stem Cells from Adult Mouse Liver and Stomach Cells. Science, 321, 699-702. http://dx.doi.org/10.1126/science.1154884

[89] Eminli, S., Foudi, A., Stadtfeld, M., et al. (2009) Differentiation Stage Determines Reprogramming Potential of Hematopoietic Cells into Induced Pluripotent Stem Cells. Nat Genet, 41, 968-976. http://dx.doi.org/10.1038/ng.428

[90] Eminli, S., Utikal, J., Arnold, K., Jaenisch, R. and Hochedlinger, K. (2008) Reprogramming of Neural Progenitor Cells into Induced Pluripotent Stem Cells in the Absence of Exogenous Sox2 Expression. Stem Cells, 26, 2467-2474. http://dx.doi.org/10.1634/stemcells.2008-0317

[91] Shao, L. and Wu, W.-S. (2010) Gene-Delivery Systems for iPS Cell Generation. Expert Opinion on Biological Therapy, 10, 231-242. http://dx.doi.org/10.1517/14712590903455989

[92] Soldner, F., Hockemeyer, D., Beard, C., et al. (2009) Parkinson's Disease Patient-Derived Induced Pluripotent Stem Cells Free of Viral Reprogramming Factors. Cell, 136, 964-977. http://dx.doi.org/10.1016/j.cell.2009.02.013

[93] Nishimura, K., Sano, M., Ohtaka, M., et al. (2011) Development of Defective and Persistent Sendai Virus Vector: A Unique Gene Delivery/Expression System Ideal for Cell Reprogramming. The Journal of Biological Chemistry, 286, 4760-4771. http://dx.doi.org/10.1074/jbc.M110.183780

[94] Yu, J., Hu, K., Smuga-Otto, K., et al. (2009) Human Induced Pluripotent Stem Cells Free of Vector and Transgene Sequences. Science, 324, 797-801. http://dx.doi.org/10.1126/science.1172482

[95] Shi, Y., Do, J.T., Desponts, C., Hahm, H.S., Schöler, H.R. and Ding, S. (2008) A Combined Chemical and Genetic Approach for the Generation of Induced Pluripotent Stem Cells. Cell Stem Cell, 2, 525-528. http://dx.doi.org/10.1016/j.stem.2008.05.011

[96] Mallanna, S.K. and Rizzino, A. (2010) Emerging Roles of microRNAs in the Control of Embryonic Stem Cells and the Generation of Induced Pluripotent Stem Cells. Developmental Biology, 344, 16-25. http://dx.doi.org/10.1016/j.ydbio.2010.05.014

[97] Houbaviy, H.B., Murray, M.F. and Sharp, P.A. (2003) Embryonic Stem Cell-Specific MicroRNAs. Developmental Cell, 5, 351-358. http://dx.doi.org/10.1016/S1534-5807(03)00227-2

[98] Judson, R.L., Babiarz, J.E., Venere, M. and Blelloch, R. (2009) Embryonic Stem Cell-Specific microRNAs Promote Induced Pluripotency. Nature Biotechnology, 27, 459-461. http://dx.doi.org/10.1038/nbt.1535

[99] Anokye-Danso, F., Snitow, M. and Morrisey, E.E. (2012) How microRNAs Facilitate Reprogramming to Pluripotency. Journal of Cell Science, 125, 4179-4187. http://dx.doi.org/10.1242/jcs.095968

[100] Miyoshi, N., Ishii, H., Nagano, H., et al. (2011) Reprogramming of Mouse and Human Cells to Pluripotency Using Mature microRNAs. Cell Stem Cell, 8, 633-638. http://dx.doi.org/10.1016/j.stem.2011.05.001

[101] Anokye-Danso, F., Trivedi, C.M., Juhr, D., et al. (2011) Highly Efficient miRNA-Mediated Reprogramming of Mouse and Human Somatic Cells to Pluripotency. Cell Stem Cell, 8, 376-388. http://dx.doi.org/10.1016/j.stem.2011.03.001

[102] Vitaloni, M., Pulecio, J., Bilic, J., Kuebler, B., Laricchia-Robbio, L. and Izpisua Belmonte, J.C. (2014) MicroRNAs Contribute to Induced Pluripotent Stem Cell Somatic Donor Memory. The Journal of Biological Chemistry, 289, 20842098. http://dx.doi.org/10.1074/jbc.M113.538702

[103] Narsinh, K.H., Plews, J. and Wu, J.C. (2011) Comparison of Human Induced Pluripotent and Embryonic Stem Cells: Fraternal or Identical Twins? Molecular Therapy, 19, 635-638. http://dx.doi.org/10.1038/mt.2011.41

[104] Vaskova, E.A., Stekleneva, A.E., Medvedev, S.P. and Zakian, S.M. (2013) “Epigenetic Memory” Phenomenon in In- 
duced Pluripotent Stem Cells. Acta Naturae, 5, 15-21.

[105] Liu, L., Luo, G.-Z., Yang, W., et al. (2010) Activation of the Imprinted Dlk1-Dio3 Region Correlates with Pluripotency Levels of Mouse Stem Cells. The Journal of Biological Chemistry, 285, 19483-19490. http://dx.doi.org/10.1074/jbc.M110.131995

[106] Liu, P., Chen, S., Li, X., et al. (2013) Low Immunogenicity of Neural Progenitor Cells Differentiated from Induced Pluripotent Stem Cells Derived from Less Immunogenic Somatic Cells. PLoS ONE, 8, e69617. http://dx.doi.org/10.1371/journal.pone.0069617

[107] Alberts, B. (2015) Molecular Biology of the Cell. 6th Edition, Garland Science, Taylor and Francis Group, New York.

[108] Richly, H., Aloia, L. and Di Croce, L. (2011) Roles of the Polycomb Group Proteins in Stem Cells and Cancer. Cell Death \& Disease, 2, e204. http://dx.doi.org/10.1038/cddis.2011.84

[109] Chamberlain, S.J., Yee, D. and Magnuson, T. (2008) Polycomb Repressive Complex 2 Is Dispensable for Maintenance of Embryonic Stem Cell Pluripotency. Stem Cells, 26, 1496-1505. http://dx.doi.org/10.1634/stemcells.2008-0102

[110] Harrison, T.R., Ed. (1962) Harrison's Principles of Internal Medicine. McGraw-Hill, New York.

[111] Soldner, F. and Jaenisch, R. (2012) iPSC Disease Modeling. Science, 338, 1155-1156. http://dx.doi.org/10.1126/science.1227682

[112] Ebert, A.D. and Svendsen, C.N. (2010) Stem Cell Model of Spinal Muscular Atrophy. JAMA Neurology, 67, 665-669. http://dx.doi.org/10.1001/archneurol.2010.89

[113] Ebert, A.D., Yu, J., Rose, F.F., et al. (2009) Induced Pluripotent Stem Cells from a Spinal Muscular Atrophy Patient. Nature, 457, 277-280. http://dx.doi.org/10.1038/nature07677

[114] Kim, C. (2014) Disease Modeling and Cell Based Therapy with iPSC: Future Therapeutic Option with Fast and Safe Application. Blood Research, 49, 7-14. http://dx.doi.org/10.5045/br.2014.49.1.7

[115] Mercola, M., Colas, A. and Willems, E. (2013) Induced Pluripotent Stem Cells in Cardiovascular Drug Discovery. Circulation Research, 112, 534-548. http://dx.doi.org/10.1161/CIRCRESAHA.111.250266

[116] Drawnel, F.M., Boccardo, S., Prummer, M., et al. (2014) Disease Modeling and Phenotypic Drug Screening for Diabetic Cardiomyopathy Using Human Induced Pluripotent Stem Cells. Cell Reports, 9, 810-821. http://dx.doi.org/10.1016/j.celrep.2014.09.055

[117] Singh, V.K., Kalsan, M., Kumar, N., Saini, A. and Chandra, R. (2015) Induced Pluripotent Stem Cells: Applications in Regenerative Medicine, Disease Modeling, and Drug Discovery. Frontiers in Cell and Developmental Biology, 3, 2. http://dx.doi.org/10.3389/fcell.2015.00002

\section{List of Abbreviations}

$\begin{array}{ll}\text { c-Myc } & \text { c-Myelocytomatosis } \\ \text { EBs } & \text { Ebryoid Bodies } \\ \text { ECM } & \text { Extracellular Matrix } \\ \text { hESCs } & \text { Human Embryonic Stem Cells } \\ \text { ICM } & \text { Inner Cell Mass } \\ \text { iPSCs } & \text { Induced Pluripotent Stem Cells } \\ \text { Klf4 } & \text { Krupple Like Factor-4 } \\ \text { LIF } & \text { Leukemia Inhibitory Factor } \\ \text { MHC } & \text { Major Histocompatibility Complex } \\ \text { mESCs } & \text { Mouse Embryonic Stem Cells } \\ \text { NIH } & \text { National Institute of Health } \\ \text { Oct4 } & \text { Octamer-4 } \\ \text { Sox2 } & \text { Sry Box Containing Gene 2 }\end{array}$

